\title{
Corporate debt, firm size and financial fragility in emerging markets is
}

\author{
Laura Alfaro $^{\mathrm{a}, \mathrm{d}, *}$, Gonzalo Asis $^{\mathrm{b}}$, Anusha Chari ${ }^{\mathrm{b}, \mathrm{d}}$, Ugo Panizza ${ }^{\mathrm{c}, \mathrm{e}}$ \\ a Harvard University, Business School, Morgan 461, Boston, MA 02163, United States \\ b University of North Carolina at Chapel Hill, Department of Economics, CB \#3305, Chapel Hill. NC 27599, United States \\ c The Graduate Institute, Geneva, The Graduate Institute of International and Development Studies. Maison de la Paix (Chemin Eugène-Rigot2) Petale 1, \#664. Case Postale 136, CH1211 Genève 21, Switzerland \\ d NBER, United States \\ e CEPR, United Kingdom
}

\section{A R T I C L E I N F O}

\section{Article history:}

Received 10 November 2017

Received in revised form 1 January 2019

Accepted 2 January 2019

Available online 8 February 2019

Research data related to this submission: https:// data.mendeley.com/datasets/4cgbgr2nnt/draft? $a=c 62647 f d-612 d-4 b 2 a-b d 77-06 a f 0 b d b 5 c a a$

\section{JEL Classification:}

F34

G01

G15

G32

Keywords:

Emerging Markets

Corporate Debt

Financial Fragility

Firm-Level Data

Large Firms

\section{A B S T R A C T}

The post-Global Financial Crisis period shows a surge in corporate leverage in emerging markets and a number of countries with deteriorated corporate financial fragility indicators (Altman's Z-score). Firm size plays a critical role in the relationship between leverage, firm fragility and exchange rate movements in emerging markets. While the relationship between firm-leverage and distress scores varies over time, the relationship between firm size and corporate vulnerability is relatively time-invariant. All else equal, large firms in emerging markets are more financially vulnerable and also systemically important. Consistent with the granular origins of aggregate fluctuations in Gabaix (2011), idiosyncratic shocks to the sales growth of large firms are positively and significantly correlated with GDP growth in our emerging markets sample. Relatedly, the negative impact of exchange rate shocks has a more acute impact on the sales growth of the more highly levered large firms.

\section{Introduction}

There was a rapid credit expansion in emerging-market countries in the aftermath of the Global Financial Crisis (GFC). A surge in foreign borrowing and deterioration in net external debt positions accompanied the increase in domestic credit (BIS, 2014; IMF, 2015). The non-financial corporate sector accounts for the lion's share of this surge in leverage including significant increases in international bond issuance (Fig. 1). The total domestic and foreign debt of emerging market-based non-financial firms rose from \$2.4 trillion to \$3.7 trillion, and outstanding international bonds grew from $\$ 360$ billion to $\$ 1.1$ trillion between 2007 and 2015 (BIS, 2016).

is We thank participants at NBER conference Capital Flows and Debt in Emerging Markets, CEPAL conference on Debt and Economic Growth, and Luis Servén and Ramón Piñeda for helpful discussions, Carmen Reinhart, Hyun Song Shin, Sebnem Kalemli-Ozcan, Nicholas Magud, Alberto Martin and Sergio Schmukler for thoughtful comments and suggestions.

* Corresponding author at: Harvard University, Business School, Morgan 461, Boston, MA 02163, United States

E-mail addresses: lalfaro@hbs.edu (L. Alfaro), gasis@live.unc.edu (G. Asis), achari@unc.edu (A. Chari), ugo.panizza@graduateinstitute.ch (U. Panizza).
Monetary policy normalization in advanced economies, rising emerging-market sovereign debt premia, low corporate profitability and market valuations all together have the potential to cause severe liquidity problems for emerging market firms. ${ }^{1}$ In fact, following taper talk and the lift-off from the zero lower bound in the United States, tight dollar funding conditions have led to sharp reversals in capital flows to emerging markets. ${ }^{2,3}$ Rising fears, notably Turkey, are that normalizing monetary

\footnotetext{
1 The growth in corporate profits has slowed considerably, and the return on invested capital in emerging-market firms has significantly declined since the financial crisis. As evidence, emerging markets usually trade at lower valuations than their advanced-economy counterparts, and while these relative valuations increased in the aftermath of the GFC, emerging markets are trading at a discount again.

2 See for example, Bloomberg. "Emerging Markets in May Saw Biggest Outflows in 18 Months", June 5, 2018; Reuters, “Emerging markets set for \$448 billion outflows this year-IIF," January 26, 2016.

${ }^{3}$ A number of direct and indirect channels can transmit shocks to highly leveraged nonfinancial corporates to the domestic economy. For example, a deterioration of credit quality of corporate borrowers or a sudden withdrawal of funds from the domestic financial system by firms that are unable to roll-over their international obligations can impair the domestic banking system (Acharya et al., 2015).
} 


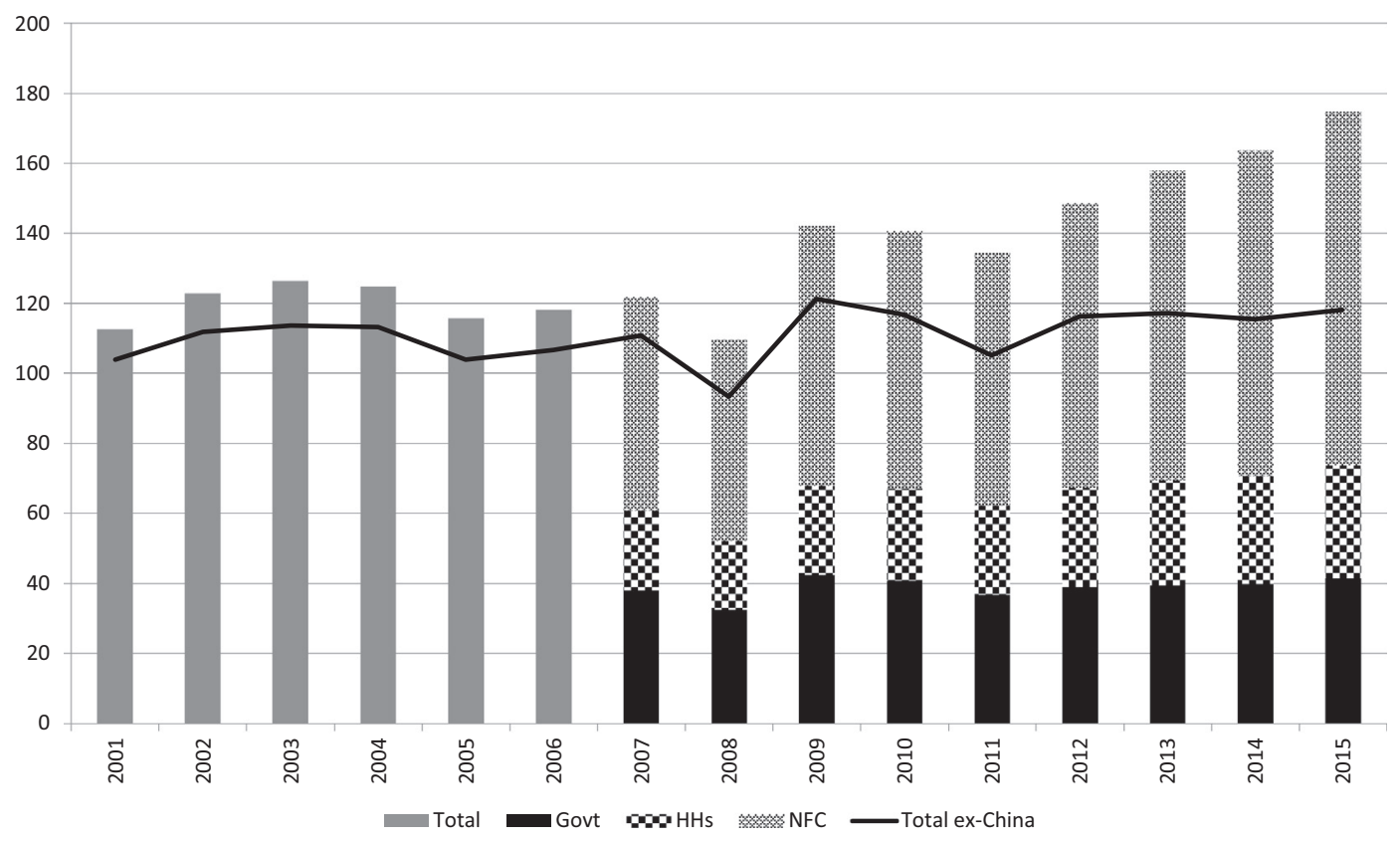

Fig. 1. Total Credit to the Non-financial Sector in Emerging Markets (\% of GDP).

Source: Authors' calculations based on BIS total credit statistics. (Decomposition across sectors is only available after 2006)

policy conditions in the US could trigger waves of corporate failures in a number of emerging economies. Understanding the potential vulnerabilities, however, requires that we know more about the state of emerging market corporate balance sheets and their hitherto unexplored impact on the macroeconomy. Our paper aims to do so.

The paper's main contribution is to investigate the role of large firms in the emerging market economies and whether their vulnerabilities portend adverse macroeconomic consequences. Gabaix (2011) notes that the largest firms dominate economic activity in advanced countries and shocks to the largest firms can affect aggregate output as these shocks do not get diversified in the aggregate data. ${ }^{4}$

We start by showing that firm size plays a critical role in the relationship between leverage, firm fragility and exchange rate movements in emerging markets. We also show that while the relationship between leverage and distress scores varies over time, the relationship between firm size and corporate vulnerability is relatively time-invariant. To our knowledge this result is new. Next, we carefully examine whether the most leveraged and financially fragile firms in emerging markets are also the most systemically important. We believe that this is the first paper to formally test Gabaix's (2011) granular origins of aggregate fluctuations hypothesis using emerging market data. The details of the analysis follow below.

We use detailed financial statement information from Worldscope and Orbis for a broad cross-section of emerging markets over a twentyyear period to study the relationship between firm characteristics such as size, leverage and corporate financial fragility over time. As a summary measure of corporate fragility, we use the widely used Altman's Z-score measure adapted to the emerging market context (Altman, 2005). ${ }^{5}$

We begin by documenting the cross-country patterns in the Altman's Z-score for the emerging markets in our sample. Next, using detailed firm-level information, we investigate the relationship between leverage and corporate financial fragility with particular

\footnotetext{
4 See also Acemoglu et al. (2016).

5 The original Altman's Z-score is a linear combination of five corporate income and balance sheet values to measure the financial health of a company: the ratios of working capital, retained earnings, and operating income to total assets, the book value of assets to total liabilities and the sales to total assets. By combining various aspects of firm operations, it paints an overall picture of corporate health (Altman, 1968).
}

emphasis on the role of firm size. We also examine the impact of macroeconomic and institutional factors such as exchange rates, economic growth, and financial globalization interacted with leverage on corporate distress scores.

We find that in the post-GFC period, many countries have higher leverage and are close to or in the Altman Z-score "grey zone" implying a higher risk of financial distress. Turkey now in distress territory is perhaps a good example. Regression estimates show that leverage has a negative correlation with the $\mathrm{Z}$ score, i.e., scores for firms with high leverage are closer to the distressed range. Further, large firms and highly levered firms are more financially vulnerable. Interestingly, the magnitude of the coefficient on firm size almost quadruples with the introduction of country-year fixed effects to control for unobserved heterogeneity across countries and is eight times larger with firm-fixed effects. Moreover, across alternative definitions of firm size, the relationship with financial vulnerability remains negative and highly statistically significant. Large firms, therefore, appear to be a principal source of corporate financial vulnerability in emerging markets.

We also find that while the relationship between leverage and fragility varies over time, the firm characteristic that is consistently significant and robust is firm size. To explain the observed country-year heterogeneity we conjecture is that if firms borrow in foreign currency, leverage will likely have a particularly adverse impact on corporate financial fragility in times of currency depreciation. The data suggest that indeed the interaction effect between leverage and currency depreciation is negative and statistically significant. The inclusion of country-year fixed effects rules out any concern of direct reverse causality, i.e., the possibility that an increase in firm fragility leads to currency depreciation.

We undertake a number of tests and explore alternative explanations to ensure the robustness of our results. The relationship between firm size and financial fragility is robust to economic recessions and tighter financial conditions. Also, the effect of firm size and leverage conditional on changes in the bilateral exchange rate vis-à-vis the U.S. dollar are robust to leverage interactions with inflation, financial development, and the updated Lane and Milesi-Ferretti (2007) index of financial globalization. Importantly, the size variable remains negative, highly statistically significant with a remarkably stable coefficient magnitude across all the specifications. 
Additional tests reveal that the relationship between firm size and corporate financial fragility is robust to the survivorship bias of firms, excluding China from the specifications and the use of a constant sample. We also find a differential interaction effect of leverage and exchange rate changes on corporate financial fragility that depends on whether emerging market currencies are strengthening or weakening the interaction effect of leverage and change in the exchange rate on $Z$-scores conditional on currency depreciation is negative and statistically significant. Concerning sector-specificity, the estimations show a larger and statistically significant interaction effect between leverage and exchange rates for non-tradable industries and a smaller and insignificant coefficient for the tradable sector.

A potential concern is that for variables measured with error, our results may suffer from attenuation bias that is amplified by the presence of firm and country-year fixed effects. To address attenuation bias, as well as other remaining endogeneity concerns, we use two instruments for the exchange rate. One based on world capital flows data (Bussière et al., 2015, and Alfaro et al., 2018) interacted with the time-varying country-specific values of the Chinn-Ito index for financial openness and a second instrument that uses currency weights computed by Bénétrix et al. (2015) to build an exogenous shock to the financially weighted exchange rate. The instrumental variables specifications confirm that the interaction effect between leverage and the exchange rate and firm size on corporate distress scores is negative and statistically significant. Importantly, the coefficient magnitudes in the instrumental variable regressions are much larger alleviating concerns about attenuation bias.

Next, we turn to the second main contribution of the paper. A fundamental question is whether the findings about firm size and leverage documented above can have adverse macroeconomic consequences especially with monetary policy normalization in advanced economies. To answer this question, we explore the role of large firms and their importance for the overall economic performance in emerging markets. Consistent with Gabaix (2011) we find that large firms are systemically important-idiosyncratic shocks to large firms significantly correlate with GDP growth in our sample of emerging markets. We see that while large firms are less levered than small firms, they may have a more risky type of leverage as large firm performance in terms of sales growth deteriorates more significantly in response to exchange rate depreciation. While this result holds for the average country in our sample, we also find that there is substantial cross-country heterogeneity. In conjunction with the contributions that large firms make to the overall economic performance in emerging markets, the leverage vulnerabilities of these firms may, therefore, warrant particular attention from policymakers.

Note again that there is considerable concern about the recent increase in dollar borrowing by emerging market firms (McCauley et al. 2015, Avdjiev et al., 2014, and Acharya et al., 2015). Our paper is the first to provide evidence of the macroeconomic consequences of the links between leverage, currency movements, and firm size. Given that disaggregate data on the liability composition (currency, maturity, type of lender) of non-financial firms are not available our tests are a valuable and novel contribution to the literature. Implicitly, there is an intimate link between the vulnerabilities of systemically large firms, bailout guarantees, and moral hazard issues in emerging market lending where widespread corporate debt vulnerabilities can turn into fullblown financial crises. Once again, Turkey is a case in point.

Our paper is related to several strands of literature. First, the paper contributes to the literature on the recent evolution of corporate debt in the aftermath of the GFC. IMF (2015) documents the main trends and shows that global factors drive the increase in corporate leverage following the GFC. This finding is in line with Shin's (2013) view that the response to the crisis led to a sudden increase in global liquidity. Acharya et al. (2015) present several case studies and evaluate vulnerabilities and potential policy responses. More generally, this paper relates to the literature documenting the association between rapid credit growth and the building of corporate leverage and financial crises (Mendoza and Terrones, 2008, and Schularick and Taylor, 2012). The paper is also related to the literature on the origins of the Asian Financial Crisis also credited with corporate financial roots. ${ }^{6}$ Our paper is also related to the growing literature on the financial channel of exchange rate changes (Bruno and Shin, 2015a). ${ }^{7}$

The paper proceeds as follows. Section 2 describes the firm-level data. Section 3 provides detailed stylized facts about leverage and corporate vulnerabilities in emerging markets including the build-up of corporate debt and our methodology for measuring corporate financial fragility. Section 4 presents firm-level regression results that explore factors that drive corporate fragility in emerging markets. Section 5 analyzes the relationship between firm size, corporate fragility and the macroeconomy. Section 6 concludes.

\section{The data}

This paper uses firm-level data from Worldscope (gathered through Datastream) and Osiris that provide information going back to the 1990s. ${ }^{8}$ The data provide a long time series that allows us to exploit the variation in the relationship between leverage, firm-size and corporate financial fragility in emerging markets over two decades and spanning a number of crises. Both sources provide detailed historical information for listed and unlisted firms for a wide sample of countries. ${ }^{9}$ We compared Worldscope and Osiris' coverage for emerging markets and chose the data source with the most data availability for each country. Osiris had better coverage for China and India, while Worldscope dominated for all other countries.

The sample consists of data on non-financial firms from 1992 to 2014 for the main countries classified as emerging markets from the MSCI's emerging market index. ${ }^{10}$ These are Argentina, Brazil, Chile, China, Colombia, Czech Republic, Hungary, India, Indonesia, Jordan, Malaysia, Mexico, Morocco, Pakistan, Peru, Philippines, Poland, Russia, Slovakia, Slovenia, South Africa, South Korea, Taiwan, Thailand, Turkey, and Vietnam. Since coverage of Eastern European countries is extremely sparse, we group together firms from Czech Republic, Hungary, Poland, Slovakia, and Slovenia into 'Eastern Europe'.

Our final sample includes all companies that have data for each indicator of firm performance described below. The number of companies with data for every variable and year of interest is too small to create a balanced sample. Nonetheless, we have performed the analysis maintaining a balanced sample during different periods, obtaining similar results

We exclude outliers and all noticeable errors in the data. The sample varies from a maximum of 7972 firms with data on leverage totaling 45,104 firm-year observations to a minimum of 2926 firms (13,653

\footnotetext{
${ }^{6}$ Pomerlano (1998) uses firm-level data and finds that excessive leverage and poor financial performance in the corporate sector caused the Asian financial crisis. Ghosh et al. (2002) also show that in 1995-96 several East Asian countries had debt ratios and shares of short-term debt which were significantly higher than debt ratios and short-term debt shares in OECD countries. Claessens et al. (2000) suggest that corporate financial risk factors may have been an amplifying factor in the crisis. Corsetti et al. (1999) also explore the root causes of the Asian Financial crisis.

7 Other papers in this literature include but are not limited to Alfaro and Kancuzk, (2013), Alfaro et al. (2017), Bruno and Shin (2015b), Claessens et al. (2015), Eichengreen and Tong (2015), Du and Schreger (2016), Galindo et al. (2003), Niepmann and SchmidtEisenlohr (2017), Druck et al. (2017), Avdjiev et al. (2018).

${ }^{8}$ The Worldscope database provides detailed historical financial statement information for the world's leading public and private companies. Osiris, published by Bureau van Dijk, has information as well on listed, and major unlisted/delisted, companies around the world. All data for tangible fixed assets is also from Osiris. While extracting data from Osiris, we restricted the sample to include sales information.

${ }^{9}$ Alternative sources, such as Orbis data, do not provide consistent historical data for private and public firms for emerging markets. For example, Di and Levchenko's (2013) show that between 2006 and 2008 there were only 44 countries (mostly OECD and Eastern European countries) for which Orbis had firm-level data on sales for at least 1000 firms.

10 We supplement these countries with Argentina, Jordan, Morocco, Slovakia, Slovenia and Vietnam. Egypt, Qatar and UAE are not in our sample due to data availability. Also, we do not include Greece as an emerging market.
} 
Table 1

Summary statistics

\begin{tabular}{|c|c|c|c|c|c|c|c|c|}
\hline & Obs & Mean & Std. Dev. & Median & P25 & P75 & Min & Max \\
\hline \multicolumn{9}{|c|}{ Firm-level variables } \\
\hline Leverage & 45,104 & 66.36 & 70.16 & 43.43 & 11.91 & 95.44 & 0.00 & 254.89 \\
\hline Leverage $^{a}$ & 10,491 & 69.94 & 70.10 & 47.84 & 16.78 & 99.31 & 0.00 & 254.85 \\
\hline Z Score & 13,653 & 7.49 & 4.39 & 6.86 & 4.38 & 10.31 & 0.18 & 16.55 \\
\hline Modified Z-Score & 13,653 & 25.63 & 3.35 & 25.15 & 23.53 & 27.42 & 19.92 & 33.26 \\
\hline Total Assets ${ }^{\mathrm{a}, \mathrm{b}}$ & 13,653 & 287.1 & 536.4 & 9.01 & 1.31 & 226.9 & 0.83 & 1652 \\
\hline Investment $^{\mathrm{C}}$ & 11.219 & 0.09 & 0.28 & 0.04 & -0.07 & 0.18 & -0.33 & 0.93 \\
\hline \multicolumn{9}{|c|}{ Country-level variables } \\
\hline$\Delta \mathrm{EX}$ & 401 & 0.07 & 0.20 & 0.02 & -0.03 & 0.09 & -0.25 & 1.00 \\
\hline GR_GDP & 388 & 0.06 & 0.04 & 0.06 & 0.03 & 0.10 & -0.06 & 0.12 \\
\hline Inflation & 400 & 64.6 & 37.0 & 69.9 & 40.8 & 94.2 & -1.4 & 143.6 \\
\hline FINDEV & 401 & 59.0 & 42.1 & 42.0 & 24.9 & 96.7 & 8.3 & 166.5 \\
\hline LMF & 334 & 1.15 & 0.56 & 1.03 & 0.78 & 1.36 & 0.38 & 3.86 \\
\hline
\end{tabular}

All variables are Winsorized at 5\% (a) Only firms for which we have data on the Z-Score; (b) millions USD; (c) Investment is defined as percentage change in fixed assets.

firm-year observations) with enough data to compute Altman's Emerging Market Z-score, our main measure of corporate fragility. The countries with most firms in the database are China, India, and South Korea, and with the least Eastern Europe.

Column 1 of Table A1 in the Appendix shows total sales of firms in our database by country as a percentage of the country's total market capitalization, as computed by the World Bank. We find this a better measure of sample coverage than Sales/GDP because the large majority of the firms in our database are publicly listed, and the size of the listed market relative to GDP varies significantly by country, as Column 2 shows.

\section{Stylized facts: leverage and corporate vulnerabilities in emerging markets}

\subsection{The build-up of corporate debt}

The surge in borrowing by non-financial corporations was a key driver of the increased leverage in emerging markets in the aftermath of the global financial crisis. ${ }^{11}$ Over 2001-2007 average credit to the non-financial sector in emerging market countries remained close to $120 \%$ of GDP. While the GFC caused a sudden reduction in credit, credit started expanding rapidly in 2009 and reached 175\% of GDP in 2015, a 67-percentage point increase with respect to the 2008 trough (Fig. 1). Corporate debt went from $57 \%$ to $101 \%$ of GDP over $2008-15$.

Domestic credit expansion in emerging markets was accompanied by a surge in foreign borrowing. ${ }^{12}$ Non-financial corporations also

11 Total cross-border claims on EMs by BIS reporting banks increased from $\$ 2.4$ trillion in 2008 to a peak of $\$ 3.7$ trillion on 2014. Data for 2015 indicates a $\$ 200$ billion retreat, with total cross-border claims standing just below $\$ 3.5$ trillion. In 2007 foreign currency bonds represented $16 \%$ of international debt by emerging market-based non-financial corporations and by 2014 the foreign currency share had grown to 22\% (IMF, 2015). The share of dollar-denominated bonds issued by non-financial corporations is higher than the overall share of dollar-denominated bonds. In 2015, borrowing by non-financial corporations accounted for about $25 \%$ of emerging market cross-border borrowing from BIS reporting banks. Total credit denominated in US dollars to non-bank borrowers, resident in emerging markets increased from 1.6 trillion in 2008 to 3 trillion at the end of 2014. Over the same period of time total credit denominated to non-bank borrowers, resident in emerging markets denominated in euro and Japanese yen also increased but at a much smaller rate 9and starting from a smaller base) than dollar credit (data on foreign currency credit to non-financial corporations are available the BIS Global Liquidity Indicators, Tables E2.1 E2.2, E2.3. We would like to thank an anonymous referee for suggesting this data source. 12 Total cross-border claims on EMs by BIS reporting banks increased from $\$ 2.4$ trillion in 2008 to a peak of $\$ 3.7$ trillion on 2014. Data for 2015 indicates a $\$ 200$ billion retreat, with total cross-border claims standing just below $\$ 3.5$ trillion. In 2007 foreign currency bonds represented $16 \%$ of international debt by emerging market-based non-financial corporations and by 2014 the foreign currency share had grown to 22\% (IMF, 2015). The share of dollar-denominated bonds issued by non-financial corporations is higher than the overall share of dollar-denominated bonds. In 2015, borrowing by non-financial corporations accounted for about $25 \%$ of emerging market cross-border borrowing from BIS reporting banks. Also, see Borio et al. (2011), Avdjiev et al. (2012), Lane and McQuade, (2014). played a key role in international bond issuances. Over 2008-2015, outstanding international bonds issued by non-financial corporations grew from $\$ 360$ billion (approximately 30\% of total outstanding bonds) to $\$ 1.1$ trillion ( $>40 \%$ of total outstanding bonds). The increase in leverage was particularly important in non-tradable cyclical sectors such as construction. Further, the increase in leverage and foreign currency debt documented above took place in an environment of ample global liquidity and record low policy rates in advanced economies. ${ }^{13}$

For our sample of emerging markets firms, we use as a main indicator of leverage the debt to equity ratio (a firm's total debt divided by its common equity), which indicates how much debt a company is using to finance its assets relative to its common equity. Average leverage in the full sample is $66 \%$, with a median value of $43 \%$ and ranges between 0 and $255 \%$. Leverage is slightly higher for the subsample of firms for which we have enough information to compute Altman's Z score (in this case the average value of leverage is $69 \%$ with a median value of $48 \%$, compare the first two rows of Table 1 ). Table A2 in the Appendix presents a heat map for corporate leverage as the sales-weighted debt to equity ratios across the emerging markets countries in our sample.

The heat map shows that average leverage increase from $72.8 \%$ in the run up to the GFC (2003-2007) to $95.3 \%$ in the post-GFC period (2008-2014)-a 22 percentage point increase in average leverage. ${ }^{14}$ On a country-by-country basis, post-GFC leverage is higher than its pre-crisis average for every country in our sample. A $t$-test of means confirms that the increase in leverage is statistically significant at the $5 \%$ level across the two sub-periods.

Here a point about the weighting strategy used in the heat map is worth noting. We focus on sales-weighted leverage because to measure the overall riskiness of corporate debt for the financial system in a country, we would like to assess the upper bound of the risk. ${ }^{15}$ If a few large firms are also the ones with the highest leverage, it is desirable to give a larger weight to these observations since arguably these firms have the greatest potential to generate systemic risk-we focus on these large firms in Section 5.

\footnotetext{
${ }^{13}$ Emerging market-based corporates have therefore borrowed at longer maturities and lower yields. Maturity went from the pre-crisis average of 5 years to $>6$ years and average yields decreased from 8 to $6 \%$ (IMF, 2015).

${ }^{14}$ The averages of the heat map do not perfectly match those in the summary statistics of Table 1 because the heat map shows sales-weighted averages while Table presents simple averages.

${ }^{15}$ In general, the weighted median measure attenuates the distributional consequences of observations in the tails of a distribution. In many circumstances, this adjustment is warranted to ensure that outliers do not drive the results. In other words, if a few observations skew the weighted mean, the weighted median that adjusts for non-uniform statistical weights and gives the $50 \%$ weighted percentile measure is the more appropriate statistic. 14 out of 19 countries have a higher post-GFC weighted median (results available upon request).
} 
Table 2

Altman's EM Z-score and bond rating

Source: Altman (2005).

\begin{tabular}{llllllllll}
\hline & Z' Score & & Rating & \multicolumn{2}{l}{ Z' Score } & \multicolumn{3}{c}{ Rating } \\
\hline Safe Zone & & $>$ & 8.15 & AAA & 5.65 & - & 5.85 & BBB- & Grey Zone \\
& 7.60 & - & 8.15 & AA+ & 5.25 & - & 5.65 & BB + & \\
& 7.30 & - & 7.60 & AA & 4.95 & - & 5.25 & BB & \\
& 7.00 & - & 7.30 & AA & 4.75 & - & 4.95 & BB- & \\
6.85 & - & 7.00 & A + & 4.50 & - & 4.75 & B + & \\
& 6.65 & - & 6.85 & A & 4.15 & - & 4.50 & B & \\
& 6.40 & - & 6.65 & A- & 3.75 & - & 4.15 & B- & Distress Zone \\
6.25 & - & 6.40 & BBB + & & & & & \\
& 5.85 & - & 6.25 & BBB & 3.20 & - & 3.75 & CCC + & \\
& & & & & 2.50 & - & 3.20 & CCC & \\
& & & & & 1.75 & - & 2.50 & CCC- & \\
\end{tabular}

\subsection{Measuring vulnerability: the Altman Z-score}

Altman (1968) developed the first multivariate bankruptcy prediction model and the index remains widespread in finance, accounting, and macroeconomics research. ${ }^{16}$ While many alternative failureprediction models exist, the use of the Z-Score model continues as a main or supporting tool for bankruptcy or financial distress prediction. Initial tests revealed that the Altman Z-Score had a $72 \%$ accuracy rate in predicting bankruptcy two years before the event, with a Type II error that classifies the firm as bankrupt when it does not go bankrupt of 6\% (Altman, 1968). Subsequent testing over three decades showed that the model was approximately $80 \%-90 \%$ accurate in predicting bankruptcy one year before the event, with a Type II error of approximately 15\%-20\% (Altman, 1993, 2005).

The Z-score is a linear combination of five corporate income and balance sheet values to measure the financial health of a company: the ratios of working capital, retained earnings, and operating income to total assets, the book value of assets to total liabilities and the sales to total assets. By combining various aspects of firm operations, it paints an overall picture of corporate health. The advantage of the approach is that the different ranges of "safe", "grey" and "distress" can be correlated with corporate ratings letter grades used by credit rating agencies. The Z-score statistics correspond to AAA to BBB for the safe zone, BBBto $\mathrm{B}$ - for the grey zone and $\mathrm{CCC}+$ and below for the distress zone.

The original coefficient estimates compared publicly listed firms in the manufacturing sector that had declared bankruptcy and those that had survived, matched by various characteristics namely industry and size (assets). ${ }^{17}$ The measure was subsequent modified to consider larger sample of firms, including non-manufacturing (Altman Z"-Score) firms and private firms (Altman Z'-Score).

Altman (2005) also proposed a version of the original Z-Score to account for different structural characteristics of emerging market firms; e.g. he replaces the market value of assets to the book value to adjust for the relative trading illiquidity in emerging markets compared to advanced economies.

Accordingly, as a summary measure of corporate fragility, we calculate the Altman (2005) Emerging Market Z-score that is best suited to assess the relative vulnerability of the sample of countries we consider

\footnotetext{
16 Examples of papers in macroeconomics that have used Altman's measure include Bernanke and Campbell (1988), Corbae and D'Erasmo (2017), in international economics Ağca and Celasun (2012), in finance Fazzari et al. (1988), Graham et al (2008), Van Binsbergen et al. (2010), Acharya et al. (2011), Jacobson and Von Schedvin (2015), Ben-David et al. (2016), De De Angelo et al. (2016), di Bonaccorsi and Kashyap (2017).

17 The original $Z$-score, $Z=1.2 x_{1}+1.4 x_{2}+3.3 x_{3}+0.6 x_{4}+1.0 x_{5}$, where $X_{1}=$ working capital / total assets, measuring liquid assets relative to the size of the company; $X_{2}=$ retained earnings / total assets, capturing earning ability; $X_{3}=$ earnings before interest and taxes / total assets, capturing operating efficiency relative to assets; $X_{4}=$ market value of equity / book value of total liabilities; $X_{5}=$ sales / total assets capturing total asset turnover.
}

in this paper. The measure weighs four ratios constructed using the firms' financial statements (working capital to total assets, retained earnings to total assets, operating income to total assets, and book value of equity to total liabilities) ${ }^{18}$ :

$\mathrm{EM} Z$-score $=6.56 X_{1}+3.26 X_{2}+6.72 X_{3}+1.05 X_{4}+3.25$

where $\mathrm{X}_{1}=$ working capital/ total assets, $\mathrm{X}_{2}=$ retained earnings / total assets, $\mathrm{X}_{3}=$ operating income /total assets, $\mathrm{X}_{4}=$ book value of equity /total liabilities. The constant term (derived from the median $Z$ " score for bankrupt US entities) standardizes the analysis so "that a default equivalent $(D)$ is consistent with a score below zero."

Lower Z-scores are associated with greater vulnerability and likelihood of bankruptcy. Companies with EM Z-scores $>5.85$ are considered to be in the "safe zone", scores between 5.85 and 3.75 indicate vulnerability, and scores below 3.75 indicate that the firm is in state of distress. Table 2 from Altman (2005) compares Z-scores with bond ratings.

For the firms in our sample, Table A2 in the Appendix presents a heat map for EM Z-score statistics for the countries in our sample. The table presents cross-firm averages by country for the full sample (as for Leverage, we report weighted means), in the years leading up to the GFC, and in the post-GFC period. Countries with higher Z-scores in the post-GFC period are Colombia, Eastern Europe, Malaysia, South Korea, and Indonesia. Note that South Korea was in the distress zone during the Asian Financial crisis. However, nine countries in the sample are in the grey or vulnerable zone. These countries include some of the largest emerging markets in Asia (China, India and Turkey) and Latin America (Argentina, Brazil and Mexico). In addition, thirteen countries in the sample have lower average $Z$-scores in the post-GFC period compared to pre-crisis. Although there are no countries in the distress zone postGFC, in addition to the countries in the grey zone, some of the countries are also barely in the safe zone.

If the Altman Z-score provides a leading indicator of the potential for distress, the data show that a broad set of emerging markets in the postGFC period face heightened corporate vulnerability. The average winsorized emerging market Z-score in our sample is 7.50 and corresponds to a AA rating in the safe zone. The $Z$-score ranges from 0.18 in the distress zone to 16.55 in the safe zone (Table 1 ). We also build a modified Z-score that does not include the book value of equity /total liabilities. The modified Z-score has an average value of 25.63 and ranges between 20 and 33 .

To further validate our use of Altman's EM Z-score as a proxy for the inverse of corporate financial fragility, we test its ability to predict exit from the sample. We find that firms with low Z-scores are more likely to exit the sample the next period. Specifically, we estimate the following linear probability model (we obtain similar results if we use a probit model):

$$
F_{i t}=\underset{(0.65)}{25.18^{* * *}}-\quad \begin{aligned}
& 0.14^{* *} \\
& (0.05)
\end{aligned} \times Z_{i, t-1}
$$

where $F_{i, t}$ is an indicator variable that takes a value of 100 if firm $i$ is in the sample in period $\mathrm{t}-1$ but is not in the sample in period $\mathrm{t}$ and takes value 0 if the firm is in the sample in both periods, and $Z_{i, t-1}$ is the $Z$ score in period $t-1$. The point estimates suggest that in any given year there is $25 \%$ probability that a firm will drop out of the sample, but that this probability is lower for firms with a high Z score. Specifically, a one standard deviation decrease, corresponding to a $4.4 \%$ decrease in the $Z$-score is associated with a 0.7 percentage points increase in the

\footnotetext{
18 The use of book value of equity, not market value, was motivated by a concern that equity markets may be less liquid than in developed markets. Altman (2005) adjusts the measure to consider currency devaluation vulnerability, industry adjustments (relative to U.S.); competitiveness position adjustment (dominant firms in the industry due to size, political influence, etc.); special debt issue figure (collateral or bona fide, high-quality guarantor); sovereign spread (comparison to US corporate bond of the same rating).
} 
probability that the firm will not be in the sample in the following year (this corresponds to a 3\% increase in the unconditional probability of exiting the sample). This outcome suggests that also in our sample of firms the $Z$-score is a good proxy for distance to default.

We also find that the Z-score is correlated with default in the expected direction: A higher Z-score is associated with a lower probability of default. We perform this exercise using Orbis data for 15 emerging market countries (Brazil, Chile, China, Colombia, Czech Republic, Hungary, India, Indonesia, Mexico, Pakistan, Peru, Philippines, Poland, South Africa, and South Korea) and 22 years (1996-2017), containing a total of 735,426 firm-years. We construct a default dummy that equals one on the year in which a firm's status changes from "Active" to "Bankruptcy", "Dissolved", or "Dissolved (liquidation)". There are 896 such cases. We find the correlation between Altman's Emerging Market $Z$-score and the default dummy is -0.0199 , statistically significant at the $1 \%$ level. The correlation with the modified $Z$-score with no leverage term is -0.0212 , also significant at the $1 \%$ level.

Summary: While there is substantial cross-country heterogeneity in the post-GFC period, our data suggest that a number of countries have higher leverage and close to or in the "grey zone" post-GFC implying a higher risk of financial distress. Note also that while warning lights are flashing regarding these vulnerabilities, no emerging market country was actually in crisis or in the red "distress" zone by the end of our sample period. It is, however, worth noting that the Z-score signaled an increased vulnerability in Turkey, a fact consistent with the recent crisis in Turkey.

Table 1 also presents some basic summary statistics for other variables of interest. For example, the average asset size of the firms in our sample is US\$ 287 million with a median value of US\$ 9 million. The firms in the 25th percentile for size have assets of US\$ 1.3 million while the firms in the 75th percentile have assets of US\$226 million with the largest firm with assets that amount to US\$ 1652 million. Average real investment measured by the change in property, plant and equipment is $9 \%$ with firms in the 25th percentile with $-7 \%$ investment and firms in the 75th percentile with $18 \%$ real investment rates.

\section{Corporate fragility in emerging markets: firm level evidence}

\subsection{Firm-observables and corporate fragility}

In the previous section we found that in the post-GFC period more countries are in Altman's grey zone for corporate fragility or barely above the threshold. In this section we delve further into the firm-level data and run regressions to examine the link between corporate financial fragility and leverage as well as the role of firm-characteristics-in particular firm size. We also examine the impact of macroeconomic and institutional factors such as exchange rates, economic growth, and financial globalization interacted with leverage on the corporate distress scores.

As a first step, we examine the relationship between leverage, firmsize and other firm-characteristics and the $Z$-score by estimating the following model ${ }^{19}$ :

$Z_{i, c, t}=\alpha_{i}+\delta_{c, t}+\beta_{1}$ Leverage $_{i, c, t}+\beta_{2} \operatorname{SIZE}_{i, c, t}+\beta_{3} X_{i, c, t}+\varepsilon_{i, c, t}$

where $Z_{i, c, t}$ is the $Z$-score for firm $i$, country $c$, year $t$; Leverage $_{i, c, t}$ is leverage for firm $i$, country $c$, year $t$; $X_{i, c, t}$ are measures of other firm characteristics; $\alpha_{i}$ are firm fixed effects; $\delta_{c, t}$ are country-year fixed effects; $\beta_{1}$, $\beta_{2}, \beta_{3}$ are the coefficients on leverage, size and other firmcharacteristics. The standard errors are clustered at the firm and country-year level.

We begin by examining the unconditional correlation between leverage and the Altman's Z-score, i.e., with a specification that does not

\footnotetext{
19 In the regressions, the variables are Winsorized at 5\%. The results are robust to using
} $1 \%$ Winsorization as well as no Winsorization. include compositional controls. In other words, we start by estimating specification (1), but without firm and country-year fixed effects. Unless otherwise noted our measure of size is log assets. Column 1 of Table 3 examines the impact of leverage, size and real investment (measured as the change in property, plant and equipment) on the Altman's $Z$-score- It shows that leverage is inversely correlated with the $\mathrm{Z}$ score, i.e., scores for firms with high leverage are closer to the distress range. The effect is statistically significant at the $1 \%$ level. Firm size is negative and statistically significant at the $5 \%$ level. Real investment is positively correlated with the $Z$-score but the coefficient is not statistically significant. The results suggest that the large firms and highly levered firms are more financially vulnerable.

Column 2 introduces compositional controls in the form of countryyear fixed effects as it may be the case that unobserved heterogeneity across country-years may drive both the firm-characteristics such as leverage and $Z$-scores over time. The pattern of results remains qualitatively similar with negative and statistically significant coefficients on leverage and firm size and positive and but not significant coefficient on real investment. While the magnitude of the coefficient on leverage remains relatively stable, it is interesting to note that the coefficient on firm size doubles when the country-year fixed effects are included in the specification.

A potential concern with the econometric specifications in Column 1 and 2, however, is that the ratio of Book-Value-of-Equity to Total Liabilities, a component of the Altman's Z-score, is by construction negatively correlated with our measure of leverage. Therefore, one might argue that the relationship between leverage and the Z-score is mechanically hard-wired. This subtle point is worth emphasizing as, at first pass, it may appear that "leverage is regressed on leverage."

To circumvent this concern, we construct a modified Z-score that does not include the leverage term and only includes the ratios of working capital, retained earnings and operating income to total assets. Higher values of these components drive up the Z-score and are a sign of improving corporate health (the correlation between the original Z-score and the modified Z-score is 0.76 ). Column 3 examines the relationship between leverage, firm size, real investment and the modified Altman's Z-score. The regression specification is the same as in Column 1 with the modified Z-score as the dependent variable. The coefficient on leverage is no longer statistically significant. Firm size, however, remains inversely correlated with the modified Z-score, suggesting that, for a given level of leverage, larger firms are more financially fragile. Real investment is positively correlated with firm financial health and in this case the coefficient is statistically significant.

Column 4 introduces country-year fixed effects to control for unobserved heterogeneity across countries over time. The pattern of results remains qualitatively similar for firm size and investment, but the leverage coefficient is now positive and statistically significant. Interestingly, comparing the results in Columns 3 and 4, the magnitude on the coefficient on firm size almost quadruples when country-year fixed effects are introduced. Since the results in Columns 1-4 do not control for time-invariant unobservable heterogeneity at the firm level we go on to include firm fixed effects. The results are qualitatively similar to those in Column 4, but the effect of firm size is now eight times larger than that of the estimations without firm-fixed effects. ${ }^{20}$ Column 6 introduces country-year and firm fixed effects jointly into the specification. The magnitude of the coefficient on firm size is very similar to that in Column 5.

Column 7 and 8 introduce a time-invariant dummy for firm size where a firm is defined as large if its total assets are larger than the country-year average of total assets in each country-year. While the inclusion of this time invariant dummy does not allow us to control for firm fixed effects, the results with and without country-year fixed

\footnotetext{
${ }^{20}$ We also estimated a specification with a control for the return on assets. The coefficient on firm size remains inversely correlated with the modified Z-score while the return on assets, a measure of profitability, is positively correlated with the modified Z-score.
} 
Firm fragility, leverage, and firm size

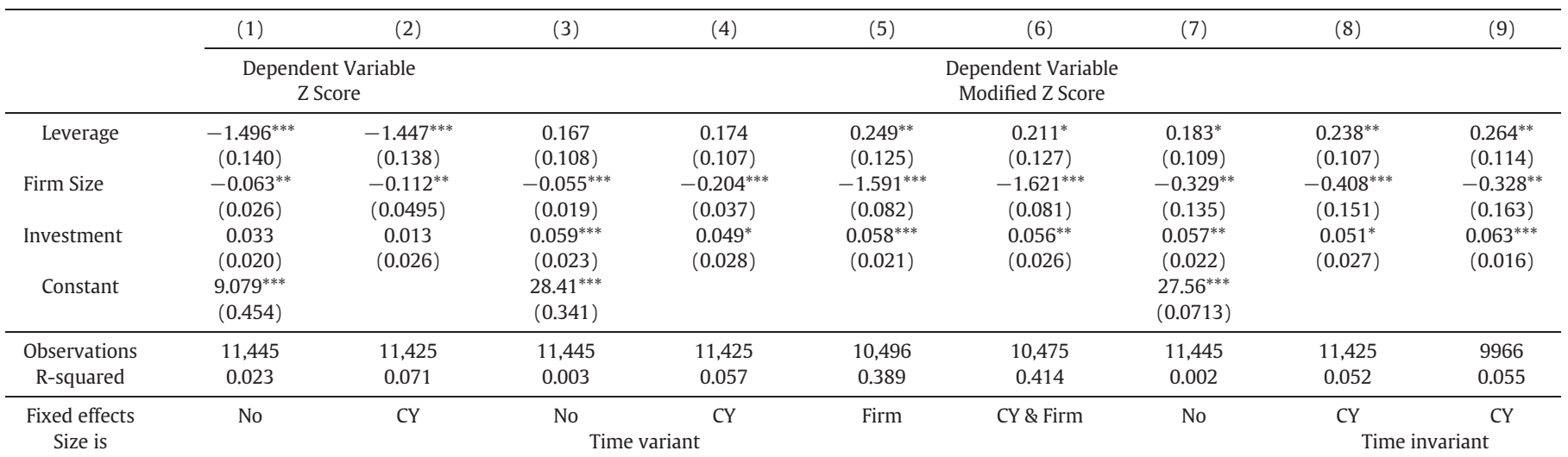

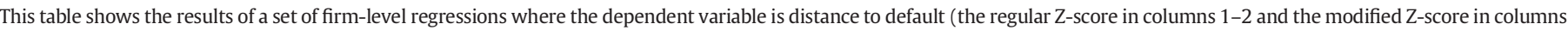

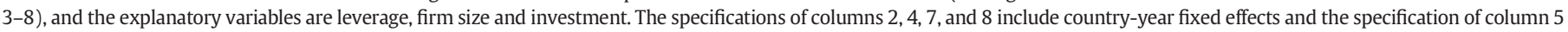

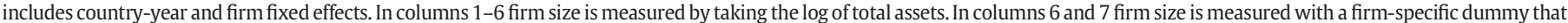

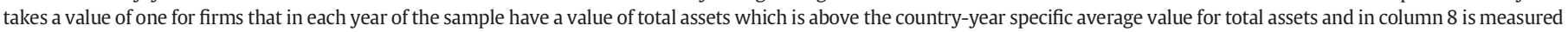

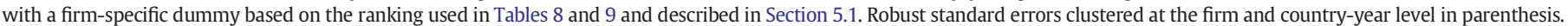

effects corroborate our previous finding that large firms tend to have lower Z-scores. In Column 9 we used an alternative measure of timeinvariant firm size. Specifically, we define firms as large on the basis of sales ranking by applying the same methodology used in the granularity regressions that examine the importance of large firms for the macroeconomy in emerging markets (see Section 5 below). ${ }^{21}$ Across these alternative definitions of firm size, the relationship with financial vulnerability remains negative and highly statistically significant. Large firms therefore appear to be a key source of corporate financial vulnerability in emerging markets.

The inverse relationship between firm-size and financial vulnerability is of interest as the financial vulnerability of large firms is of particular concern to regulators. For example, the IMF's World Economic Outlook (October 2015) report explicitly states that it is "important to closely monitor sectors and systemically important firms most exposed to risks and the sectors and large firms closely connected to them, including across the financial system, and to prepare for contingencies."

\subsection{The impact of leverage varies over time while size effect is time- invariant}

The previous subsection documents that firm size appears to be a key driver of financial fragility. In this section we examine whether the relationship between firm observables (leverage and firm size) and fragility varies over time and whether any one variable has a more consistent impact on fragility. We find that while the relationship between leverage and fragility varies over time, the firm characteristic that is consistently significant and robust to the inclusion of fixed effects is firm size.

As a first pass, we estimate regressions that allow the coefficients of leverage and firm size to vary over five different sub-periods (1993-1995, 1996-2002, 2003-2006, 2007-2010, 2011-2014). The rationale for delineating the sub-periods is as follows. The first period, 1993-1995 relates to the opening of up financial markets in emerging market countries (see Chari and Henry, 2015) ending with the Tequila Crisis of Mexico in 199495. The second period 1996-2002 corresponds to a wave of emerging market crises including the Asian financial crisis, and the Argentine and Russian crises. The third period, 2003-2007, was characterized by robust and stable growth in most emerging markets. The fourth period, 2007-

${ }^{21}$ We use these time-invariant and discrete measures of firm size to make sure that the negative correlation between firm size and the Z-score is not purely driven by within-firm shocks to the value of total assets (such shocks would create an automatic correlation between the log of total assets -our measure of firm size- and the denominator of the various components of the $\mathrm{Z}$ score).

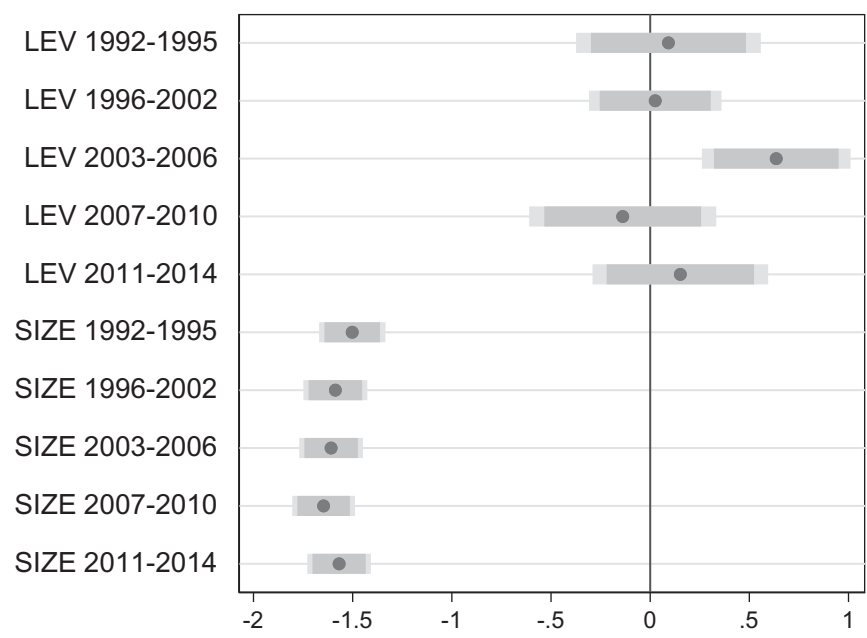

Fig. 2. Correlation between firm fragility and each of leverage and firm size. This figure plots the coefficients (with 90 and 95\% confidence intervals) of the following firm-level regression: $Z_{i, c, t}=\alpha_{i}+\delta_{c, t}+\sum_{d=1}^{5} \beta_{1, d} L E V_{i, c, t}+\sum_{d=1}^{5} \beta_{2, d} S I Z E_{i, c, t}+\varepsilon_{i, c, t}$ where $\beta_{1, d}$ and $\beta_{2, d}$ are time varying coefficients, $Z$ is the $Z$-score, LEV is leverage, SIZE is the log of total assets and $\alpha_{i}$ and $\delta_{c, t}$ are firm and country-year fixed effects

2010, coincides with the most virulent phase of the Global Financial Crisis and Great Recession. Finally, we identify $2011-2014$ as the post-Global Financial Crisis period. These periods were also characterized by important institutional changes within emerging market countries.

In the aftermath of the GFC, advanced economies were characterized by increases in government borrowing and household and corporate deleveraging. ${ }^{22}$ Emerging markets stand in stark contrast. Over 20012007 average credit to the non-financial sector in emerging market countries remained close to $120 \%$ of GDP. The GFC caused a sudden reduction in credit, which went from $122 \%$ of GDP in 2007 to $109 \%$ in 2008. Credit started expanding rapidly in 2009 and reached $175 \%$ of GDP in 2015, a 67-percentage point increase with respect to the 2008

${ }^{22}$ Low global interest rates notwithstanding, the higher leverage led to a rapid increase in the debt service ratios of emerging market borrowers. In a period when the average debt service ratio of Advanced Economies decreased from 21 to $18 \%$, the average debt service ratio of emerging markets increased from 10 to $12.5 \%$. In a subset of emerging economies characterized by rapid credit expansion, debt service ratios surpassed the advanced economy average (BIS credit statistics). 

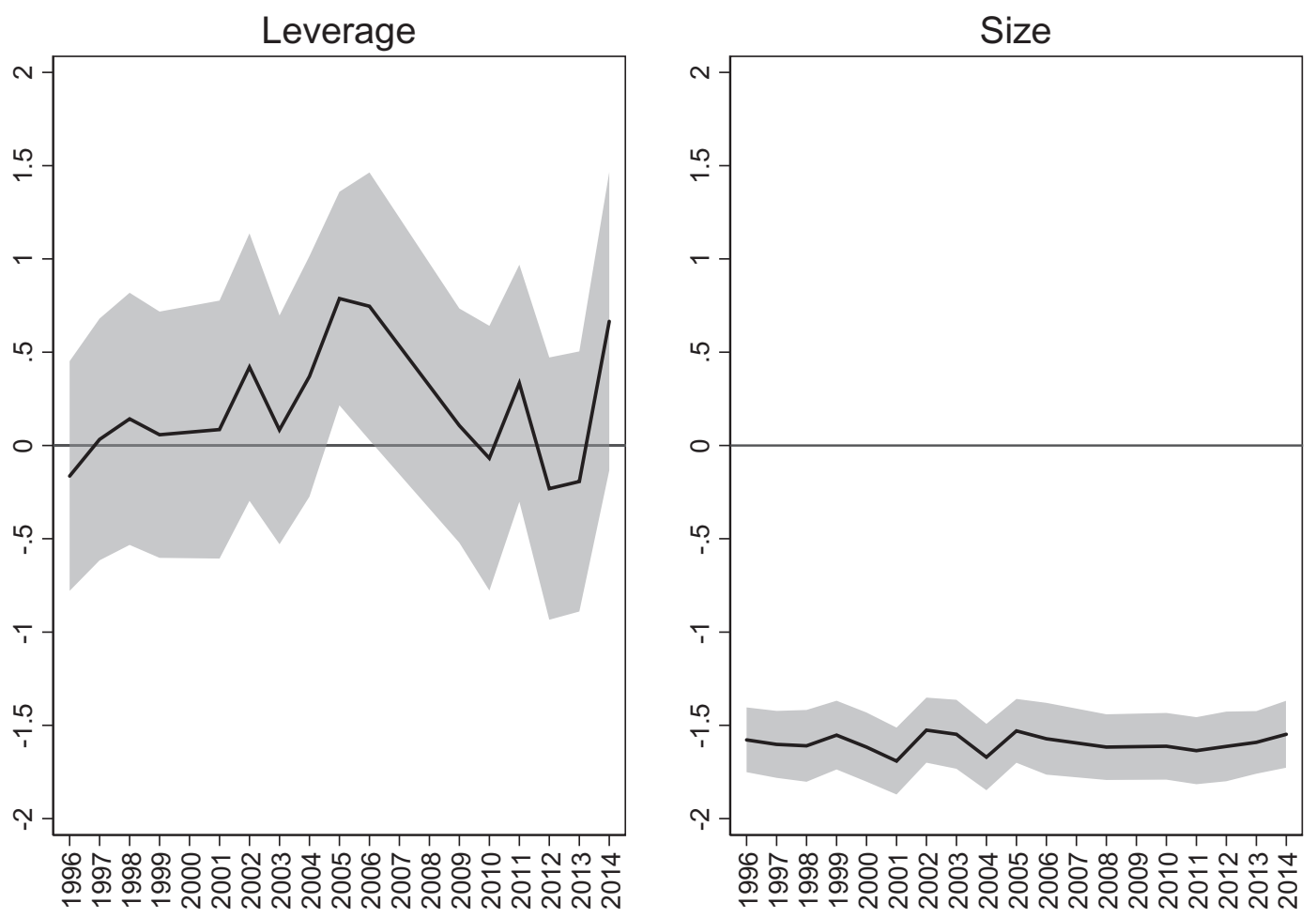

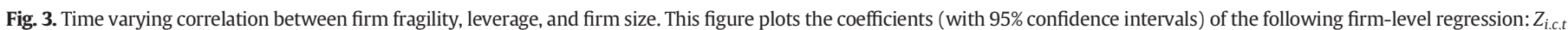

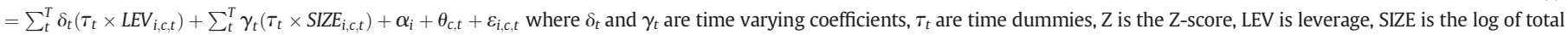
assets and $\alpha_{i}$ and $\theta_{c, t}$ are firm and country-year fixed effects.

trough (Fig. 1). Borrowing by non-financial corporations was a key driver of this surge in leverage-corporate debt went from $57 \%$ to $101 \%$ of GDP over $2008-15 .^{23}$

We estimate the following regression specification across the five sub-periods (indexed by $d$ ):

$Z_{i, c, t}=\alpha_{i}+\delta_{c, t}+\sum_{d=1}^{5} \beta_{1, d}$ Leverage $_{i, c, t}+\sum_{d=1}^{5} \beta_{2, d} \operatorname{SIZE}_{i, c, t}+\varepsilon_{i, c, t}$

The sub period regressions include firm and country-year fixed effects ( $\alpha_{i}$ and $\delta_{c, t}$, respectively). Fig. 2 reports the results that show that the coefficient on leverage is positive and significant between 2003 and 2006, and not statistically significant in other sub-periods. The pattern of coefficients suggests that the relationship between leverage and fragility varies over time. In contrast, the coefficient on firm size remains negative and statistically significant across all five sub-periods. The magnitude of the coefficient also remains remarkably stable. These simple regressions indicate that the relationship between firm size and corporate fragility is very consistent and robust.

Next, we show that the results described above are not driven by a particular choice of time period and explore the heterogeneity in the relationship between firm size, leverage and corporate fragility in detail. First, we focus on time heterogeneity and estimate the following specification.

$Z_{i, c, t}=\sum_{t}^{T} \delta_{t}\left(\tau_{t} \times L E V_{i, c, t}\right)+\sum_{t}^{T} \gamma_{t}\left(\tau_{t} \times \operatorname{SIZE}_{i, c, t}\right)+\alpha_{i}+\theta_{c, t}+\varepsilon_{i, c, t}$

where $\tau_{t}$ are year fixed effects, $\alpha_{i}$ are firm fixed effects, and $\theta_{c, t}$ are country-year fixed effects, and $\delta_{t}$ and $\gamma_{t}$ are parameter estimates. Fig. 3

23 Over the same period, household debt increased by 12 percentage points and government debt increased by 9 percentage points. plots the values of $\delta_{t}$ and $\gamma_{t}$ with $95 \%$ confidence interval. The figure confirms that the estimated effect of firm size (right panel) remains quite stable and that of leverage (left panel) varies over time (albeit is never statistically significant).

Next, we focus on country heterogeneity and estimate:

$\begin{aligned} Z_{i, c, t}= & \sum_{c}^{c} \delta_{c}\left(\eta_{c} \times \text { Leverage }_{i, c, t}\right)+\sum_{c}^{c} \gamma_{c}\left(\eta_{c} \times \operatorname{SIZE}_{i, c, t}\right)+\alpha_{i}+\theta_{c, t} \\ & +\varepsilon_{i, c, t}\end{aligned}$

where $\eta_{c}$ is a country fixed effect and all other variables are defined as above. Again, we see considerable heterogeneity for $\delta_{c}$, the coefficient on leverage (left panel) and limited heterogeneity in the magnitude of the coefficient for firm size, $\gamma_{c}$ (Fig. 4).

Finally, we allow the coefficients on leverage and size to vary across country-years and estimate:

$$
Z_{i, c, t}=\sum_{c, t}^{C T} \delta_{c, t}\left(\theta_{c, t} \times \text { Leverage }_{i, c, t}\right)+\sum_{c, t}^{C T} \gamma_{c, t}\left(\theta_{c, t} \times \text { Size }_{i, c, t}\right)+\theta_{c, t}+\varepsilon_{i, c, t}
$$

The figures once again display a lot of heterogeneity for $\delta_{c t}$ on leverage and limited heterogeneity for $\gamma_{c t}$ or firm size (Fig. 5).

\subsection{Leverage, the macroeconomy and firm size}

A natural question arises. Can we explain the observed country-year heterogeneity? One conjecture is that if firms borrow in foreign currency, leverage will likely have a particularly adverse impact on corporate financial fragility in times when the currency depreciates. We test this hypothesis by interacting leverage with changes in the bilateral exchange rate vis-à-vis the U.S. dollar (an increase is a depreciation). 

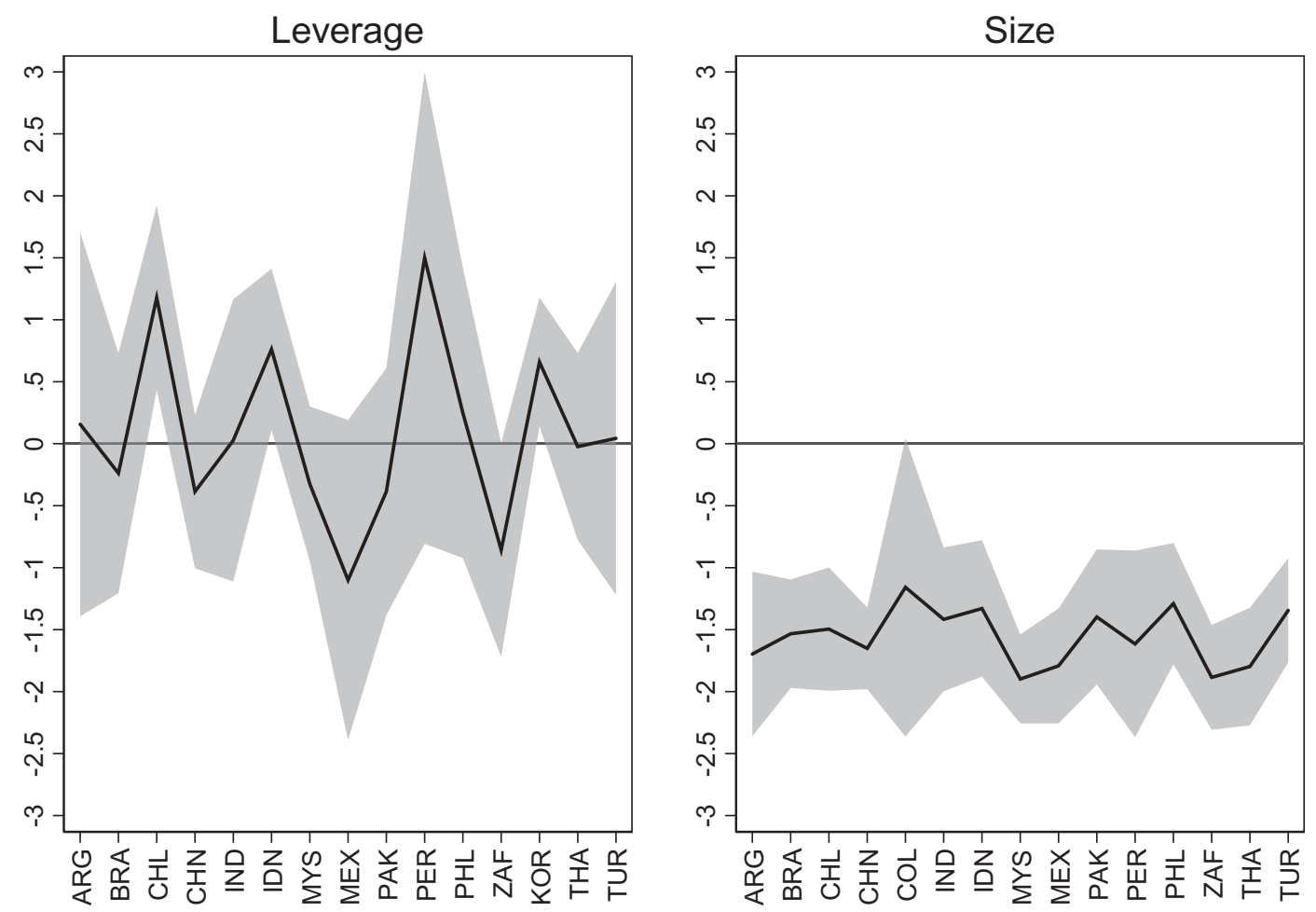

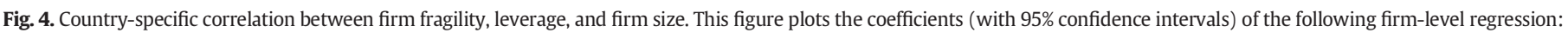

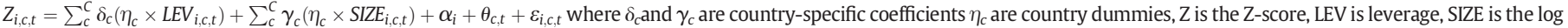
of total assets and $\alpha_{i}$ and $\theta_{c, t}$ are firm and country-year fixed effects.
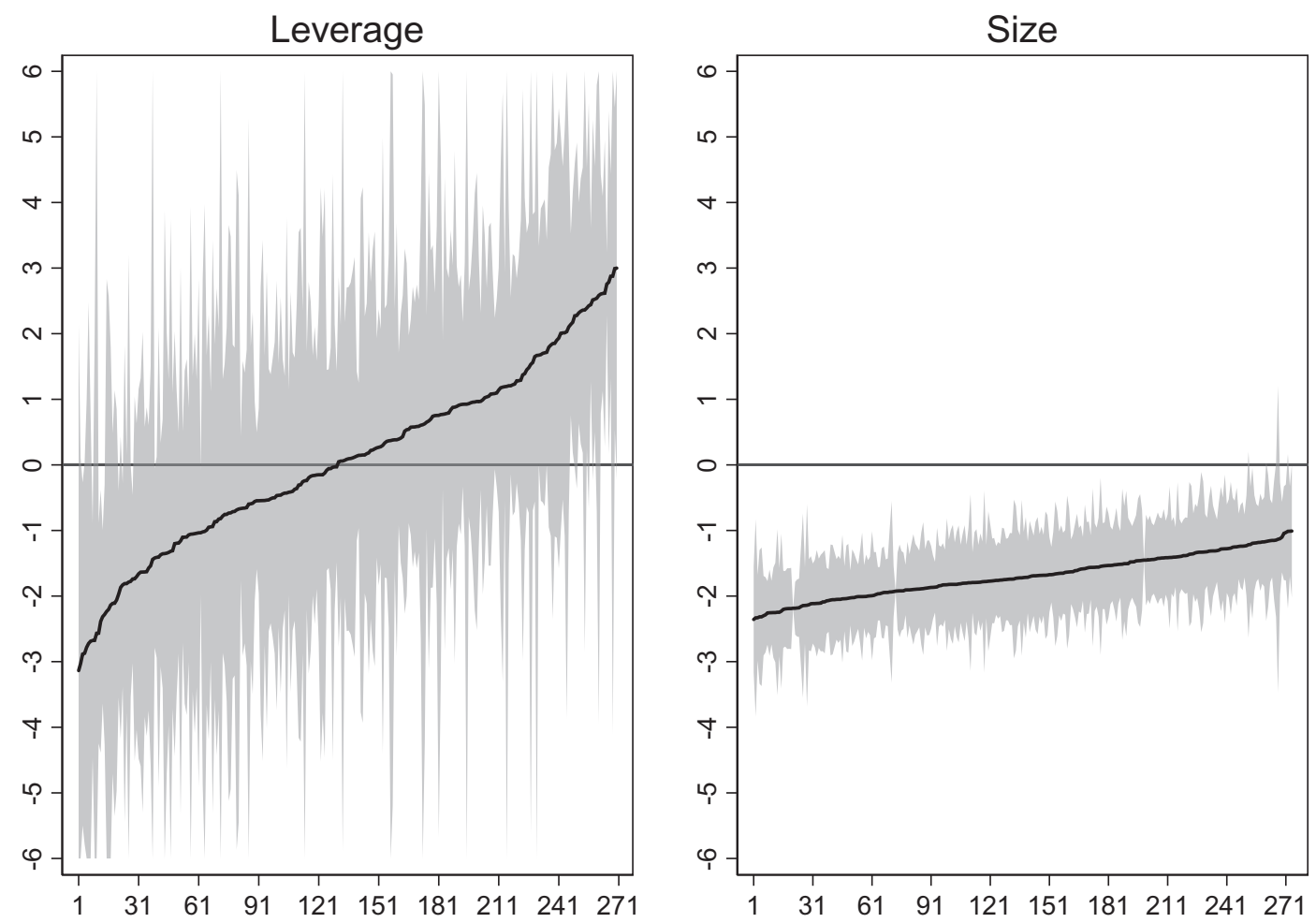

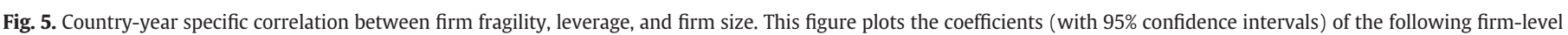

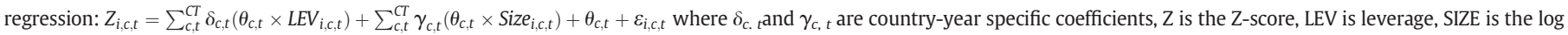
of total assets and $\theta_{c, t}$ are country-year fixed effects. 
Table 4

Firm fragility, leverage, and firm size, the role of macroeconomic shocks

\begin{tabular}{|c|c|c|c|c|c|c|c|c|c|}
\hline & (1) & (2) & (3) & (4) & (5) & (6) & (7) & (8) & (9) \\
\hline Leverage & $\begin{array}{l}0.236^{* *} \\
(0.117)\end{array}$ & $\begin{array}{c}0.170 \\
(0.116)\end{array}$ & $\begin{array}{c}0.286 \\
(0.205)\end{array}$ & $\begin{array}{c}0.170 \\
(0.266)\end{array}$ & $\begin{array}{c}0.228 \\
(0.212)\end{array}$ & $\begin{array}{c}-0.0187 \\
(0.268)\end{array}$ & $\begin{array}{c}0.191 \\
(0.518)\end{array}$ & $\begin{array}{c}0.343 \\
(0.830)\end{array}$ & $\begin{array}{c}0.490 \\
(0.893)\end{array}$ \\
\hline Firm Size & $\begin{array}{c}-1.586^{* * * *} \\
(0.073)\end{array}$ & $\begin{array}{c}-1.627^{* * * *} \\
(0.074)\end{array}$ & $\begin{array}{c}-1.552^{* * * *} \\
(0.075)\end{array}$ & $\begin{array}{c}-1.587^{* * * *} \\
(0.074)\end{array}$ & $\begin{array}{c}-1.586^{* * * *} \\
(0.073)\end{array}$ & $\begin{array}{c}-1.604^{* * * *} \\
(0.083)\end{array}$ & $\begin{array}{c}-1.575^{* * * *} \\
(0.086)\end{array}$ & $\begin{array}{c}-1.582^{* * * *} \\
(0.104)\end{array}$ & $\begin{array}{c}-1.615^{* * * *} \\
(0.157)\end{array}$ \\
\hline Leverage $\times \Delta E X$ & $\begin{array}{c}-1.046^{* *} \\
(0.487)\end{array}$ & $\begin{array}{c}-0.994^{*} \\
(0.545)\end{array}$ & $\begin{array}{c}-1.181^{* *} \\
(0.539)\end{array}$ & $\begin{array}{c}-1.040^{* *} \\
(0.485)\end{array}$ & $\begin{array}{c}-1.041^{* *} \\
(0.496)\end{array}$ & $\begin{array}{c}-1.106^{* *} \\
(0.480)\end{array}$ & $\begin{array}{c}-1.496^{* * *} \\
(0.545)\end{array}$ & $\begin{array}{c}-1.459^{* *} \\
(0.705)\end{array}$ & $\begin{array}{l}-0.436 \\
(3.685)\end{array}$ \\
\hline Leverage $\times G R \_G D P$ & & & $\begin{array}{c}0.884 \\
(2.632)\end{array}$ & & & & $\begin{array}{c}2.924 \\
(3.373)\end{array}$ & $\begin{array}{c}1.610 \\
(4.612)\end{array}$ & $\begin{array}{c}1.861 \\
(6.606)\end{array}$ \\
\hline Leverage $\times$ Inflation & & & & $\begin{array}{c}0.018 \\
(0.069)\end{array}$ & & & $\begin{array}{l}-0.051 \\
(0.082)\end{array}$ & $\begin{array}{l}-0.064 \\
(0.153)\end{array}$ & $\begin{array}{c}0.011 \\
(0.110)\end{array}$ \\
\hline Leverage $\times$ FINDEV & & & & & $\begin{array}{c}0.001 \\
(0.002)\end{array}$ & & $\begin{array}{l}-0.001 \\
(0.003)\end{array}$ & $\begin{array}{l}-0.001 \\
(0.004)\end{array}$ & $\begin{array}{l}-0.005 \\
(0.006)\end{array}$ \\
\hline Leverage $\times$ LMF & & & & & & $\begin{array}{c}0.242 \\
(0.208)\end{array}$ & $\begin{array}{c}0.210 \\
(0.233)\end{array}$ & $\begin{array}{c}0.181 \\
(0.349)\end{array}$ & $\begin{array}{c}0.334 \\
(0.434)\end{array}$ \\
\hline Observations & 13,104 & 13,374 & 12,226 & 13,104 & 13,104 & 11,045 & 10,278 & 5583 & 3949 \\
\hline R-squared & 0.428 & 0.431 & 0.426 & 0.428 & 0.428 & 0.444 & 0.443 & 0.461 & 0.518 \\
\hline Firm and Country-Year FE & Yes & Yes & Yes & Yes & Yes & Yes & Yes & Yes & Yes \\
\hline Sample & All & All & All & All & All & All & All & Depreciations & Appreciations \\
\hline Exchange rate & Bilateral & $\begin{array}{c}\text { Financially } \\
\text { weighted }\end{array}$ & Bilateral & Bilateral & Bilateral & Bilateral & Bilateral & Bilateral & Bilateral \\
\hline
\end{tabular}

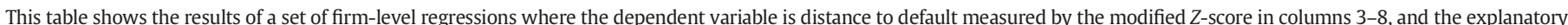

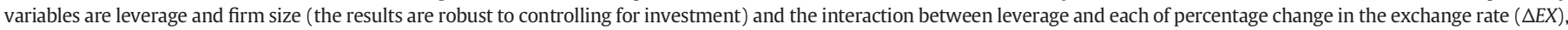

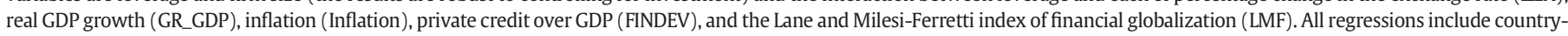

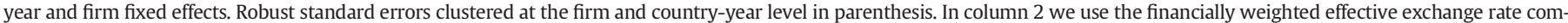
puted by Benetrix, Lane and Shambaugh.

While we do not have data on the currency composition of firm-level debt, the finding that currency movements amplify the correlation between leverage and corporate financial fragility would be consistent with the presence of currency mismatches. We test this hypothesis by estimating the following specification:

$Z_{i, c, t}=\alpha_{i}+\delta_{c, t}+\beta L_{i, c, t}+\gamma\left(L_{i, c, t} \times \Delta E X_{c, t-1}\right)+\varphi S I Z E_{i, c, t}+\varepsilon_{i, c, t}$

In this set up, $\beta$ measures the correlation between leverage and firm fragility when there are no exchange rate movements and $\gamma$ measures how the correlation between leverage and firm fragility varies with currency depreciations ( $\triangle E X_{c, t-1}$ is the percentage change in the nominal exchange rate, where $\Delta E X>0$ represents a currency depreciation). Note that the main effect of the exchange rate is captured by the country-year fixed effects.

Table 4 presents the results. Column 1 shows that the interaction effect of leverage and currency depreciation is negative and statistically significant at the $5 \%$ level (we discuss the economic significance of this effect in sub section 4.5 below). Note that the inclusion of country-year fixed effects rules out any concern of direct reverse causality, i.e., the possibility that an increase in firm fragility leads to currency depreciation. We also explore whether our baseline results (which use bilateral exchange rates vis-à-vis the US dollar) are robust to replacing the bilateral exchange rate with the financial liabilities weighted effective exchange rate computed by Bénétrix et al. (2015). Column 2 of Table 4 shows that this is the case.

However, in emerging markets, currency depreciations are often accompanied by economic recessions and tighter financial conditions. Our earlier results on the impact of exchange rates could thus be driven by the fact that highly leveraged firms suffer more during recessions or, in the presence of maturity mismatches, are particularly affected by sudden increases in the interest rate. In column 3 we control for this possibility by interacting leverage with lagged GDP growth. We find that the interaction between leverage and economic growth is not statistically significant while the interaction between leverage and currency depreciations remains negative and statistically significant.

Many emerging market countries reacted to the crises of the late 1990s with reforms aimed at improving their institutional and macroeconomic framework. Fourteen of the twenty-five countries included in our sample moved to an inflation-targeting framework between 1997 and 2009. Many countries and also implemented reforms aimed at improving their domestic capital markets (the Asian Bond market Initiative was a specific outcome of the Asian Financial crisis) and promoting financial deepening. In our sample of countries average financial depth went from 50\% in 1995 to $72 \%$ in 2014 . The period we study was also characterized by different phases of financial globalization with an increase of cross-border capital flows over 2002-2007, a collapse over 2007-2009 and a rapid increase in flows to emerging markets after 2010 (Lane and Milesi-Ferretti, 2007). Next, we test whether our results are driven by these factors by examining the effects of leverage conditional on changes in the exchange rate are robust to the inclusion of the interaction of leverage with (i) lagged inflation, (ii) an index of financial development, and (iii) the updated Lane and MilesiFerretti (2007) index of financial globalization.

Columns 4-6 show that, inflation, financial depth and international financial integration measured by the Lane and Milesi-Ferretti index interacted with leverage do not have a statistically significant impact on Z-scores, while the interaction between leverage and currency depreciation remains negative and statistically significant. Column 7 presents a full-blown estimation with all the explanatory variables from Columns $2-5$ and shows that the exchange rate and leverage effect remain robust. A second salient finding is that the size variable remains negative, statistically significant at the $1 \%$ level with a remarkably stable coefficient magnitude across all the specifications in Table 4 . The pattern once again corroborates the role of firm size in explaining corporate fragility.

To examine whether there is a differential interaction effect of leverage and exchange rate changes on corporate financial fragility depends on whether emerging market currencies are strengthening or weakening, we estimate the regression specification in Column 6 separately for periods of currency appreciation and depreciations. Columns 8 and 9 in Table 4 report the results. Column 7 shows that effect of leverage and change in the exchange rate on Z-scores conditional on currency depreciation is negative and statistically significant at the $5 \%$ level. In contrast, Column 8 shows that the coefficient on the interaction effect and the exchange rate change conditional on currency appreciation is not statistically significant. This pattern corroborates the hypothesis that leverage interacted with currency depreciation has a statistically significant adverse impact on Z-scores. 
Table 5

Firm fragility, leverage, and firm size, the role of the exchange rate in tradable and nontradable industries

\begin{tabular}{|c|c|c|c|c|}
\hline & (1) & (2) & (3) & (4) \\
\hline Leverage & $\begin{array}{c}0.267 \\
(0.173)\end{array}$ & $\begin{array}{c}0.131 \\
(0.164)\end{array}$ & $\begin{array}{c}1.334^{*} \\
(0.744)\end{array}$ & $\begin{array}{l}-0.745 \\
(0.688)\end{array}$ \\
\hline Firm Size & $\begin{array}{c}-1.506^{* * *} \\
(0.102)\end{array}$ & $\begin{array}{c}-1.681^{* * *} \\
(0.0987)\end{array}$ & $\begin{array}{c}-1.431^{* * * *} \\
(0.121)\end{array}$ & $\begin{array}{c}-1.720^{* * * *} \\
(0.116)\end{array}$ \\
\hline Leverage $\times \Delta E X$ & $\begin{array}{c}-1.409^{* *} \\
(0.653)\end{array}$ & $\begin{array}{l}-0.682 \\
(0.665)\end{array}$ & $\begin{array}{c}-1.524^{*} \\
(0.830)\end{array}$ & $\begin{array}{l}-0.971 \\
(0.689)\end{array}$ \\
\hline Leverage $\times G R \_G D P$ & & & $\begin{array}{l}-0.681 \\
(4.167)\end{array}$ & $\begin{array}{c}2.756 \\
(5.011)\end{array}$ \\
\hline Leverage $\times$ Inflation & & & $\begin{array}{c}-0.306^{* *} \\
(0.127)\end{array}$ & $\begin{array}{c}0.149 \\
(0.102)\end{array}$ \\
\hline Leverage $\times$ FINDEV & & & $\begin{array}{l}-0.00176 \\
(0.00457)\end{array}$ & $\begin{array}{c}0.00108 \\
(0.00437)\end{array}$ \\
\hline Leverage $\times$ LMF & & & $\begin{array}{c}0.280 \\
(0.329)\end{array}$ & $\begin{array}{c}0.227 \\
(0.289)\end{array}$ \\
\hline Observations & 5273 & 7680 & 4142 & 6015 \\
\hline R-squared & 0.443 & 0.449 & 0.456 & 0.464 \\
\hline $\begin{array}{l}\text { Firm and CY FE } \\
\text { Sample }\end{array}$ & $\begin{array}{c}\text { Yes } \\
\text { Non-tradable }\end{array}$ & $\begin{array}{c}\text { Yes } \\
\text { Tradable }\end{array}$ & $\begin{array}{c}\text { Yes } \\
\text { Non-tradable }\end{array}$ & $\begin{array}{c}\text { Yes } \\
\text { Tradable }\end{array}$ \\
\hline
\end{tabular}

This table shows the results of a set of firm-level regressions where the dependent variable is distance to default measured by the modified Z-score in columns 3-8, and the explanatory variables are leverage and firm size (the results are robust to controlling for investment) and the interaction between leverage and the percentage change in the exchange rate $(\triangle E X)$, real GDP growth (GR_GDP), inflation (Inflation), private credit over GDP (FINDEV), and the Lane and Milesi-Ferretti index of financial globalization (LMF). Columns 1 and 3 only include firms that operate in non-tradable sectors and columns 2 and 4 only include firms that operate in tradable sectors. All regressions include country-year and firm fixed effects. Robust standard errors clustered at the firm and country-year level in parenthesis.

We conducted a few additional tests to ensure the robustness of the patterns the data reveal. First, an important concern is whether survivorship bias drives the observed pattern of results. To address this, in Appendix Table A3 we re-estimate the specification in Column 1 of Table 4 with firms that survive or are present in the data for different lengths of time. We limit the sample to firms that are present for at least five years (column 2), for at least ten years (column 3) and for at least fifteen years (column 4). Interestingly, the coefficient estimates for both the leverage and exchange rate interaction effect and that on firm size rise in magnitude as we proceed from a sample with a fewer number of years in Column 2 to a sample with firms with data for fifteen years in Column 4. Second, we re-estimate the specifications in Table 4 by dropping China from the sample (Appendix Table A4). The pattern of results remains robust. Finally, we show that our results are robust to estimating all the models of Table 4 on a constant sample (Appendix Table A5).

\subsection{Leverage, exchange rates and tradability}

Unhedged currency exposures for firms in non-tradable industries such as construction and utilities that access international capital markets may be particularly adverse. However, currency mismatches may be less damaging for firms that, by operating in the tradable sector, may have natural hedges through foreign currency revenues. Pooling tradable and non-tradable firms into a single specification obscures such heterogeneity.

To focus on the sector-specific dimension, we estimate Eq. (2) separately for firms that operate in tradable sectors and firms that operate in non-tradable sectors. ${ }^{24}$ Columns 1 and 2 of Table 5

\footnotetext{
${ }^{24}$ We start by classifying as non-tradable all firms that have a SIC2 code above 39, but then we also classify as non-tradable firms with SIC2 codes 7 (Agricultural Services), 9 (Fishing, Hunting and Trapping), 15 (Construction - General Contractors \& Operative Builders), 16 (Heavy Construction, Except Building Construction, Contractor), 17 (Construction - Special Trade Contractors), 25 (Furniture and Fixtures), 27 (Printing, Publishing and Allied Industries), and 32 (Stone, Clay, Glass, and Concrete Products). This classification yields 5888 observations in the tradable sector and 4000 in the non-tradable sector. Our results are robust to using the simpler above 39 and below split.
}

show that a larger and statistically significant interaction effect between leverage and exchange rates for non-tradable industries and a smaller and insignificant coefficient for the tradable sector. In columns 3 and 4 we also include the interaction effects between leverage and the percentage change in the exchange rate $(\Delta E X)$, real GDP growth (GR_GDP), inflation (Inflation), private credit over GDP (FINDEV), and the Lane and Milesi-Ferretti index of financial globalization (LMF). The results show that, again the effect is only present for firms that operate in non-tradable sectors-the coefficient on the interaction effect between leverage and the exchange rate remains negative and statistically significant. Interestingly, the interaction effect between leverage and inflation is also negative and statistically significant for the non-tradable sector. In all regressions of Table 5, firm size continues to be inversely correlated with the Zscore for both tradable and non-tradable sectors.

\subsection{Attenuation bias and an instrumental variable approach}

A point to note is that the magnitude of the interaction effect between leverage and currency depreciations documented in Table 4 is small. For instance, consider how a currency depreciation of $30 \%$ may affect a firm whose leverage is one standard deviation above average. Given that the standard deviation of leverage is about 70\%, a currency depreciation of 30\% implies a Z-score reduction of 0.315 points-we use the interaction effect coefficient from Column 6 of Table $4\left(-1.5^{*} 0.30^{*} 0.7=0.315\right)$. This is a very small effect, $<10 \%$ of the standard deviation of the modified $Z$ score. Note that the effect remains small even when we focus on non-tradable industries. If our variables are measured with error, our results may suffer from attenuation bias that is amplified by the presence of firm and country-year fixed effects. Instrumental variable estimates could address this problem, as well other remaining endogenity concerns.

Our instrument is based on world capital flows (Bussière et al. (2015) and Alfaro et al., 2018). To instrument for the exchange rate, we interact world capital flows (total foreign liabilities summed across countries from the IMF, IFS) with a country's sensitivity to capital flows measured by lagged values of de jure financial openness. We proxy the financial openness measure by the Chinn and Ito (2006) index, which is based on the IMF Annual Report on Exchange Arrangements and Exchange Restrictions. The rationale for this instrument is that world gross financial flows ought to be independent of local economic conditions in a given destination country and act as a push factor. Country-specific financial openness measures provide the cross-country variation in the instrument.

In particular, we compute world capital flows as the sum of equity (FDI and portfolio) and debt inflows across countries (IMF, IFS). We then interact this variable that varies over time, with the lagged country-specific value of the Chinn-Ito index for financial openness. We normalize the measure by world GDP. We tried alternative measures that exclude reserves accumulation from total capital flows. We also used total foreign liabilities capital flows from Lane and Milesi-Ferretti. In addition, we tried pre-sample measures of the Chinn-Ito index for financial openness (1993, 1995, 2000).

Table 6 documents the relationship between corporate vulnerability and leverage, firm size, and exchange rates. Column 1 shows that the coefficients on the interaction effect between leverage and the exchange rate and on firm size are negative and statistically significant at the $5 \%$ level. Column 2 reveals a similar pattern of results for a full-blown specification that includes the full set of controls discussed in Table 4.

The instrumental variables specification confirms the effects we document in earlier sections about the drivers of corporate vulnerability. The high values of the Cragg-Donald F statistics reported at the bottom 
Table 6

Firm fragility, leverage, and firm size, IV regressions

\begin{tabular}{|c|c|c|c|c|c|c|}
\hline & (1) & (2) & (3) & (4) & (5) & (6) \\
\hline Leverage & $\begin{array}{l}1.209^{* *} \\
(0.480)\end{array}$ & $\begin{array}{l}-0.512 \\
(0.492)\end{array}$ & $\begin{array}{l}1.114^{* * *} \\
(0.430)\end{array}$ & $\begin{array}{l}-0.559 \\
(0.501)\end{array}$ & $\begin{array}{l}1.079^{* *} \\
(0.428)\end{array}$ & $\begin{array}{l}-0.604 \\
(0.499)\end{array}$ \\
\hline Firm Size & $\begin{array}{c}-1.572^{* * * *} \\
(0.098)\end{array}$ & $\begin{array}{l}-1.520^{* * *} \\
(0.074)\end{array}$ & $\begin{array}{c}-1.586^{* * * *} \\
(0.098)\end{array}$ & $\begin{array}{c}-1.520^{* * *} \\
(0.074)\end{array}$ & $\begin{array}{c}-1.585^{* * *} \\
(0.097)\end{array}$ & $\begin{array}{l}-1.521^{* * *} \\
(0.074)\end{array}$ \\
\hline Leverage $\times \Delta E X$ & $\begin{array}{l}-20.73^{* *} \\
(8.241)\end{array}$ & $\begin{array}{l}-4.957^{* *} \\
(2.169)\end{array}$ & $\begin{array}{c}-24.83^{* * * *} \\
(9.563)\end{array}$ & $\begin{array}{l}-5.614^{* *} \\
(2.458)\end{array}$ & $\begin{array}{l}-23.96^{* *} \\
(9.501)\end{array}$ & $\begin{array}{l}-6.113^{* *} \\
(2.412)\end{array}$ \\
\hline Leverage $\times G R \_G D P$ & & $\begin{array}{l}12.31^{* * *} \\
(4.646)\end{array}$ & & $\begin{array}{l}10.62^{* * *} \\
(4.064)\end{array}$ & & $\begin{array}{l}11.25^{* * *} \\
(4.021)\end{array}$ \\
\hline Leverage $\times$ Inflation & & $\begin{array}{l}-0.109 \\
(0.075)\end{array}$ & & $\begin{array}{l}-0.110 \\
(0.075)\end{array}$ & & $\begin{array}{l}-0.113 \\
(0.075)\end{array}$ \\
\hline Leverage $\times$ FINDEV & & $\begin{array}{c}-0.007^{* *} \\
(0.003)\end{array}$ & & $\begin{array}{l}-0.009^{* * *} \\
(0.003)\end{array}$ & & $\begin{array}{l}-0.009^{* * *} \\
(0.003)\end{array}$ \\
\hline Leverage ×LMF & & $\begin{array}{l}0.898^{* * *} \\
(0.281)\end{array}$ & & $\begin{array}{l}1.069^{* * *} \\
(0.334)\end{array}$ & & $\begin{array}{l}1.121^{* * *} \\
(0.330)\end{array}$ \\
\hline Observations & 8334 & 7216 & 8543 & 7216 & 8543 & 7216 \\
\hline R-squared & 0.315 & 0.463 & 0.324 & 0.463 & 0.334 & 0.462 \\
\hline $\begin{array}{l}\text { Firm and CY FE } \\
\text { Sample }\end{array}$ & $\begin{array}{l}\text { Yes } \\
\text { All }\end{array}$ & $\begin{array}{l}\text { Yes } \\
\text { All }\end{array}$ & $\begin{array}{l}\text { Yes } \\
\text { All }\end{array}$ & $\begin{array}{l}\text { Yes } \\
\text { All }\end{array}$ & $\begin{array}{l}\text { Yes } \\
\text { All }\end{array}$ & $\begin{array}{l}\text { Yes } \\
\text { All }\end{array}$ \\
\hline $\begin{array}{l}\text { Exchange rate is } \\
\text { Instruments }\end{array}$ & \multicolumn{4}{|c|}{$\begin{array}{l}\text { Bilateral rate with US\$ } \\
\text { World Capital Flows } \times \text { Financial Openness }\end{array}$} & \multicolumn{2}{|c|}{$\begin{array}{l}\text { Financially weighted effective exchange rate } \\
\text { World Capital Flows } \times \text { Financial Openness } \\
\text { and liability weighted } \$ \text { XR of main financial partners }\end{array}$} \\
\hline $\begin{array}{l}\text { Cragg-Donald F Statistics } \\
P \text { value of Sargan test }\end{array}$ & 68 & 341 & 72 & 436 & $\begin{array}{c}36 \\
0.22\end{array}$ & $\begin{array}{l}227 \\
0.25\end{array}$ \\
\hline
\end{tabular}

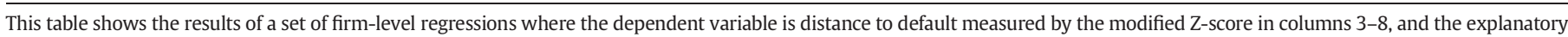

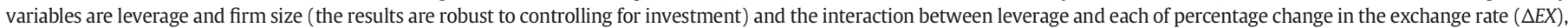

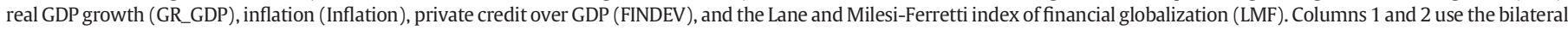

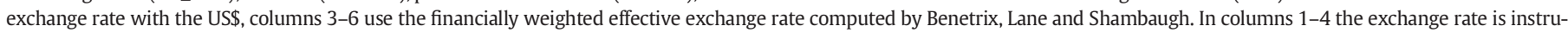

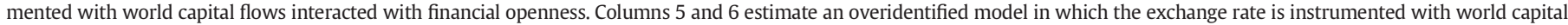

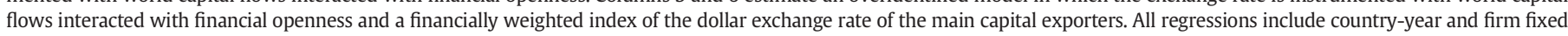
effects. Robust standard errors clustered at the firm and country-year level in parenthesis.

of the table show that our results are not affected by a weak instrument problem. $^{25}$

The magnitudes of the coefficients in the instrumental variable regressions are much larger alleviating concerns about attenuation bias. Quantifying the interaction effect of leverage and exchange rates for a $30 \%$ depreciation results in a $Z$-score fall of $4.8^{*} 0.3 * 0.7=1$ point. This means that if the currency depreciates by $30 \%$, the $Z$ score drops by 1 point or about one-third of a standard deviation in the distribution of the modified Z-score.

We estimated the specifications in Columns 1 and 2 using the alternative financially weighted exchange rate measure of Bénétrix et al. (2015). The results remain robust (Columns 3 and 4). One advantage of using the financially weighted exchange rate is that this effective exchange rate allows us to use an additional instrument and thus assess the validity of our IV strategy with an over-identification test.

Specifically, we propose a second instrument that uses timeinvariant currency weights computed by Bénétrix et al. (2015) to build an exogenous shock to the financially weighted exchange rate. To fix the ideas, consider a world with three currencies: the peso, U.S. dollar, and the euro. The financially-weighted effective exchange rate for the peso would be:

$E_{p}=w E_{p / \$}+(1-w) E_{p / €}$

where $E_{p / \$}$ is pesos per dollar, $E_{p / €}$ is pesos per euro, and $w$ is the weight of the dollar in the effective exchange rate for the peso. Also define $E_{\$ / €}$ as dollars per euro which we assume is exogenous to developments in the country that issues the peso. As $E_{p / €}=E_{p / \$} E_{p / €}$, we can

${ }^{25}$ Note that since we are instrumenting an interaction, the instrument is itself interacted with leverage. therefore rewrite the effective exchange rate as:

$E_{p}=E_{p / \$}\left[w+(1-w) E_{\$ / €}\right]$

Given that currency weights tend to be relatively stable over time, the preceding analysis implies that we can use $(1-w) E_{\$ / €}$ as an instrument for the effective exchange rate for the peso, $E_{p}$. Given that we have more than three currencies, we instrument the financially weighted exchange rate of country $i$ in time $t\left(E_{i, t}\right)$ with $\left(1-w_{i}\right) E_{U S, t}$, where $w_{i}$ is the time-invariant (computed as an average over 1990-2010) of the US dollar share in country i's financially weighted exchange rate and $E_{U S, t}$ is the effective exchange rate for the US. ${ }^{26}$

Columns 5 and 6 of Table 6 show that the results of columns 3 and 4 are robust to including this instrument together with the world capital flows instrument of Alfaro et al. (2018). The interaction effect between leverage and the new instrument for the exchange rate is negative and significant as is the unconditional effect on leverage. Size also continues to be inversely correlated with corporate vulnerability. The coefficient on growth interacted with leverage is positive and significant. The bottom rows of the table show that the instruments are not weak and that the Sargan test does not reject the validity of our over-identifying assumptions.

\section{Corporate fragility in emerging markets and the macroeconomy}

A key question is whether the increase in corporate leverage documented above can have large negative macroeconomic consequences with monetary policy normalization in advanced economies. Acharya et al. (2015) suggest that this normalization could lead to capital outflows from emerging markets and potential problems

\footnotetext{
${ }^{26}$ Note that we could have done this exercise with any other currency, but we picked the dollar as it is the currency that tends to have the largest weight in the financially weighted exchange rate of most emerging market countries.
} 
Table 7

The granularity effect

\begin{tabular}{cccc}
\hline & $(1)$ & $(2)$ & $(3)$ \\
\hline G & $0.591^{* *}$ & $0.709^{* * *}$ & $0.696^{* *}$ \\
& $(0.230)$ & $(0.255)$ & $(0.264)$ \\
L2.G & & $0.463^{*}$ & $0.428^{*}$ \\
& & $(0.240)$ & $(0.245)$ \\
& & & -0.129 \\
Observations & 486 & & $(0.08)$ \\
\hline Number of countries & 26 & 486 & 486 \\
\hline Country fixed effects & Yes & 26 & 26 \\
Year fixed effects & Yes & Yes & Yes \\
Sample & $1994-2014$ & $1994-2014$ & $1994-2014$ \\
\hline
\end{tabular}

This table reports a set of regression in which the dependent variable is per-capita GDP growth and the explanatory variables are granularity (G) and its first two lag (L.G and L2.G). All the regressions control for country and year fixed effects. Robust standard errors clustered at the country level in parenthesis.

associated with the presence of currency mismatches in firm balance sheets.

Note that in all the specifications in Tables 3-5 that included firm size, size was a significant predictor of financial vulnerability. Moreover, the coefficient was highly statistically significant. The inverse correlation between firm size and the Altman's Z-score (both the standard and modified versions), suggest that in emerging markets firm size or the extent of granularity in the firm-level data may be a novel and powerful indicator of financial vulnerabilities.

Hence, we study macroeconomic vulnerabilities by focusing on the behavior of large firms. Specifically, we proceed in two steps. First, we follow Gabaix (2011) and show that idiosyncratic shocks to large firms are significantly correlated with GDP growth in our sample of emerging markets. Second, we test whether large firms are particularly vulnerable to exchange rate movements. We find that large firms are, on average, less leveraged than smaller firms. However, we also find that the more-leveraged large firms are more vulnerable to exchange rate shocks compared to equally-leveraged smaller firms. This evidence is consistent with the idea that large firms make a greater use of foreign currency borrowing and that they are not fully hedged against exchange rate movements. While this result holds for the average country in our sample, we also find that there is substantial cross-country heterogeneity.

\subsection{Granularity in emerging markets}

Gabaix (2011) shows that if the distribution of firm size can be approximated with a fat-tailed power law (formally $P(S>x)=a x^{-\xi}$ where $S$ is firm size and $\xi \geq 1$ ) idiosyncratic firm-level shocks can play a key role in explaining aggregate fluctuations. He builds a "granularity" index that captures idiosyncratic shocks for the largest 100 US firms and shows that this index is closely correlated with overall US GDP growth (Table A6 in the Appendix shows that this correlation is robust to including additional controls).

According to Gabaix, granularity effects are likely to be even more important in countries that are less diversified than the United States. He mentions several emerging market countries and suggests that "It would be interesting to transpose the present analysis to those countries" (Gabaix, 2011 p. 737). We take this suggestion seriously and build a granularity index for our sample of 26 emerging market countries.

Gabaix (2011) measures granularity with the following index:

$\Gamma_{t}=\sum_{i=1}^{K} \frac{S_{i, t-1}}{Y_{i, t-1}}\left(g_{i, t}-\bar{g}_{t}\right)$

where $S_{i, t-1}$ measures sales of firm $i, Y_{i, t-1}$ is GDP, $g_{i, t}$ is the growth rate of firm $i$ (defined as the growth rate of the sales to employees
Table 8

Fragility and firm size

\begin{tabular}{|c|c|c|c|c|}
\hline & (1) & (2) & (3) & (4) \\
\hline & Leverage & Solvency & Liquidity & Z-Score \\
\hline Large & $\begin{array}{c}-15.82^{* * * *} \\
(2.606)\end{array}$ & $\begin{array}{c}1.737 \\
(1.648)\end{array}$ & $\begin{array}{c}0.392 \\
(0.944)\end{array}$ & $\begin{array}{c}0.124 \\
(0.265)\end{array}$ \\
\hline $\begin{array}{c}\text { Observations } \\
\text { Sample }\end{array}$ & $\begin{array}{c}44,104 \\
\text { All }\end{array}$ & $\begin{array}{c}38,741 \\
\text { All }\end{array}$ & $\begin{array}{c}39,271 \\
\text { All }\end{array}$ & $\begin{array}{c}16,653 \\
\text { All }\end{array}$ \\
\hline $\begin{array}{c}\text { Country FE } \\
\text { Year FE }\end{array}$ & $\begin{array}{l}\text { Yes } \\
\text { Yes }\end{array}$ & $\begin{array}{l}\text { Yes } \\
\text { Yes }\end{array}$ & $\begin{array}{l}\text { Yes } \\
\text { Yes }\end{array}$ & $\begin{array}{l}\text { Yes } \\
\text { Yes }\end{array}$ \\
\hline
\end{tabular}

This table reports a set of regression in which the dependent variables are various measures of potential or realized fragility (leverage, solvency, liquidity, and distance to default) and the explanatory variable is a dummy variable taking the value of 1 for large firms (Large). All the regressions control for country and year fixed effects. Robust standard errors clustered at the firm and country-year level in parenthesis.

ratio) and $\bar{g}_{t}$ is the simple average of the growth rate of the largest $Q$ firms in the economy (with $Q \geq K$, and where firm size is measured by sales). Gabaix sets $K=100$ and experiments with $Q=100$ and $Q=$ 1000 . When $Q=100$, the index is equal to the weighted growth rate of the 100 largest firms minus the (simple) average growth rate of these same firms. When $Q=1000$, the index is equal to the weighted growth rate of the 100 largest firms minus the (simple) average growth rate of the largest 1000 firms. It should be noted that the weights $\left(\frac{S_{i, t-1}}{Y_{i, t-1}}\right)$ do not add up to one because the weights are computed for a subset of firms and the numerator is sales and the denominator is GDP.

In order to build a granularity index for our sample of emerging markets we need to address two issues. The first issue relates to data limitations. As mentioned above, Gabaix measures firm growth as the growth rate of the sales-to-employees ratio. Unfortunately, we do not have a good coverage of firms with data on total employment. Therefore, we measure firm growth by focusing on the growth rate of total sales. Our measure is a good approximation of the salesto-employees growth rate as long as most of the variance in the ratio used by Gabaix arises from variations in sales rather than in variations of employment.

The second issue relates to the definition of "large" firms in an emerging market context. While it is reasonable to assume that, in a large and diversified economy like the United States, the largest 100 firms are indeed very large, this assumption is problematic in smaller and less diversified emerging market countries.

One possible way to address this issue is to simply use a smaller number of firms for all countries in our sample. In choosing this number however the number of firms needs to be large enough to capture some variability in idiosyncratic shocks and cover a meaningful share of overall GDP. Among the various possible thresholds, the largest number that allows us to include all the countries in our sample is 25 .

An alternative strategy is to use a criterion based on the share of total sales over GDP. For instance, we can rank firms in descending order of size and impose a cumulative sales-to-GDP ratio threshold. Formally, let $f_{1, c, t}$ be total sales of the largest firm (by sales) in country c, year $t$, $f_{2, c, t}$, the sales of the second largest, and $f_{n, c, t}$ the sales of the $\mathrm{n}^{\text {th }}$ largest firm. Let $x$ be a threshold in terms of cumulated sales of over GDP. Then firm are defined as large up to the point where:

$$
\sum_{i=1}^{N} \frac{f_{i, c, t}}{G D P_{c, t}}<x
$$

We experimented, with different thresholds and found that most country-years in our sample reach the level of $20 \%$ of the cumulative sales-to-GDP ratio. ${ }^{27}$ One issue is that in countries with high degrees

${ }^{27}$ As before there are tradeoffs in the choice of the threshold $x$. If the threshold is too low there will be too few "large" firms and if the threshold is too high there will be many countries in our sample with few listed firms that do not reach a higher threshold. 
Table 9

Leverage, depreciation and firm size

\begin{tabular}{|c|c|c|c|c|c|c|}
\hline & (1) & (2) & (3) & (4) & (5) & (6) \\
\hline Leverage & $\begin{array}{c}-0.0261 \\
(0.129)\end{array}$ & $\begin{array}{c}-0.0451 \\
(0.129)\end{array}$ & $\begin{array}{c}0.342 \\
(0.277)\end{array}$ & $\begin{array}{l}-0.111 \\
(0.147)\end{array}$ & $\begin{array}{l}-0.129 \\
(0.142)\end{array}$ & $\begin{array}{c}-0.284 \\
(0.217)\end{array}$ \\
\hline Leverage $\times \Delta E X$ & $\begin{array}{l}-0.069 \\
(0.074)\end{array}$ & $\begin{array}{l}-0.097 \\
(0.073)\end{array}$ & $\begin{array}{c}-0.793^{* * *} \\
(0.152)\end{array}$ & $\begin{array}{c}-0.0914 \\
(0.0858)\end{array}$ & $\begin{array}{l}-0.0361 \\
(0.0742)\end{array}$ & $\begin{array}{l}-0.0388 \\
(0.0751)\end{array}$ \\
\hline Large & $\begin{array}{c}-748.2^{* * *} \\
(35.79)\end{array}$ & $\begin{array}{c}-991.3^{* * *} \\
(43.13)\end{array}$ & & & $\begin{array}{c}-988.7^{* * *} \\
(43.25)\end{array}$ & $\begin{array}{c}-771.1^{* * *} \\
(43.05)\end{array}$ \\
\hline$\triangle E X$ & $\begin{array}{l}-8.078 \\
(5.150)\end{array}$ & & & & & \\
\hline Large $\times \Delta E X$ & & & & & $\begin{array}{c}30.25^{*} \\
(17.18)\end{array}$ & $\begin{array}{c}11.54 \\
(15.83)\end{array}$ \\
\hline Leverage $\times$ Large & & & & & $\begin{array}{c}0.388 \\
(0.279)\end{array}$ & $\begin{array}{l}0.688^{* *} \\
(0.302)\end{array}$ \\
\hline Leverage $\times \Delta E X \times$ Large & & & & & $\begin{array}{c}-0.866^{* * *} \\
(0.177)\end{array}$ & $\begin{array}{c}-0.823^{* * *} \\
(0.170)\end{array}$ \\
\hline Observations & 40,674 & 40,674 & 8616 & 31,024 & 40,674 & 20,504 \\
\hline Number of firms & 0.108 & 0.124 & 0.288 & 0.121 & 0.124 & 0.241 \\
\hline Sample & All & All & Large Firms & Small Firms & All & Largest 150 \\
\hline Firm FE & Yes & Yes & Yes & Yes & Yes & Yes \\
\hline CY FE & No & Yes & Yes & Yes & Yes & Yes \\
\hline
\end{tabular}

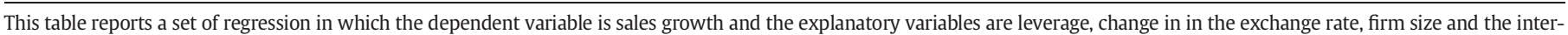

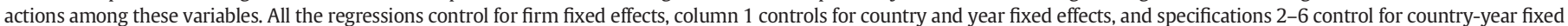
effects. Robust standard errors clustered at the firm and country-year level in parenthesis.

of concentration, a very small number of firms are sufficient to breach the threshold.

In the end, we adopt an intermediate strategy: we define as large, the largest firms for whom cumulative sales are below 20\% of GDP. However, if $<25$ firms are sufficient to reach this threshold, our definition of large is the largest 25 firms. As we do not want to include more firms than what Gabaix includes for the US, we limit the number of large firms to 100 . Summing up, we rank firms by sales and we define as large a firm $f_{i, c, t}$ if $i \leq 25$ or $\sum_{i=1}^{N} \frac{f_{i, c, t}}{G D P_{c, t}}<0.2$, and $i \leq 100$. In Table 7 we regress GDP growth over the granularity index controlling for country and year fixed effects and confirm Gabaix's intuition that granularity would be positively correlated with GDP growth in emerging market countries.

\subsection{Large firms and exchange rate vulnerabilities}

Having established that idiosyncratic shocks to large firms are correlated with GDP growth, we now examine whether leveraged large firms are more vulnerable to currency depreciations. As a first step, we check if there are differences in leverage and other potential measures of fragility between large and smaller firms. Column 1 of Table 8 shows that compared to smaller firms, lower levels of leverage characterize the large firms in the sample. Columns $2-4$ show that there are no statistically significant differences in other measures of corporate financial vulnerabilities such as solvency, liquidity, and the Z-score.

While large firms have lower leverage with respect to smaller firms, it is possible that they have an "unhealthier" type of leverage. Specifically, in the presence of fixed costs it is easier for large firms to borrow abroad, and foreign borrowing tends to be in foreign currency. There is evidence that large firms issue international bonds not only to finance investment projects but also to engage into carry trade activities (Bruno and Shin, 2017, Caballero et al., 2015). Lack of data on the currency composition of firm liabilities prevents us from directly testing if this is the case for our full sample of countries, but there is some evidence that (i) large Brazilian firms are more likely to have foreign currency debt compared to smaller firms (Bonomo et al., 2003); (ii) large firms in the U.S. use more foreign currency derivatives (Allayannis and Weston, 2001); (iii) large firms in Finland are more likely to borrow in foreign currencies than small firms (Keloharju and Niskanen, 2001); and (iv) larger firms hold a higher fraction of dollar debt in a set of firms from Argentina, Brazil, Chile, Colombia, and Mexico (Bleakley and Cowan, 2008).

Given that we cannot test directly whether currency mismatches are potentially more problematic for larger firms, we test whether sales growth (associated with GDP growth in the granularity regressions of Table 7) responds more to exchange rate movements in large and leveraged firms than in equally leveraged smaller firms. As a first step we estimate the following model for our full sample of firms:

GR_Sales $_{i, c, t}=$ Leverage $_{i, c, t}\left(\beta+\gamma \Delta E X_{c t}\right)+\delta \operatorname{Large}_{i, c, t}+\theta \Delta E X_{c t}+\alpha_{i}+\varepsilon_{i, c t, t}$

where $G R \_S a l e s_{i, c, t}$ is sales growth in firm $i$, country $c$, year $t, L E V_{i, c, t}$ is leverage, $\Delta E X_{c t}$ is the percentage change in the exchange rate in country $c$, year $t$ (positive values are depreciations), $L A R G E_{i, c, t}$ is a dummy variable that takes a value of one for large firms (defined as above), and $\alpha_{i}$ are firm fixed effects. Since we have firm fixed effects, Large captures the effect of firms that were small and become large.

Column 1 of Table 9 shows that firm size (Large) is negatively correlated with sales growth, but that the interaction between leverage and currency depreciation is not statistically significant and neither are the main effects of depreciation and leverage. The lack of a significant effect on the interaction between leverage and currency depreciations may be due to the fact that for the average firm in our sample the negative effect of depreciation is not linked to the presence of negative balance sheet effects brought about by the presence of foreign currency debt. Alternatively, the lack of statistical significance may be due to the fact that firms that have currency mismatches are less leveraged on average. As we saw earlier, large firms are less leveraged and may have larger shares of foreign currency debt. When we augment the model with countryyear fixed effects (a specification that does not allow us to separately estimate the effect of the exchange rate change, $\Delta E X$ ), we find results that are essentially identical to those of the model without country-year fixed effects (compare the first two columns of Table 9).

Next, we estimate our model with country-year fixed effects separately for large and small firms. Columns 3 and 4 of Table 9 show that the interaction between leverage and exchange rate movements is statistically significant for large firms and are not statistically significant for smaller firms.

In column 3 of Table 9, we find that the interaction coefficient on leverage and the exchange rate takes a value of -0.8 . This means that, all else equal, a currency depreciation of $30 \%$ reduces sales for the large 


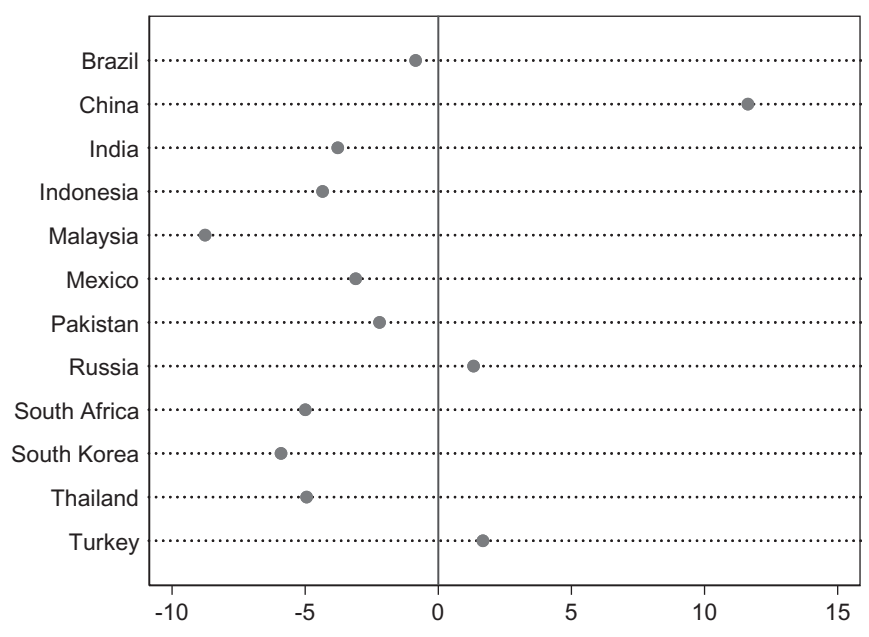

Fig. 6. Coefficient of the parameter $\psi$. This figure plots the equation the coefficient of the Parameter $\psi$ of Eq. 13 estimated one country at a time. (the model does not include country-year fixed effects but includes with year fixed effects)

firm with average leverage (the average for large firms is $55 \%$ in our sample) by approximately $13 \%\left(55^{*} 0.3^{*} 0.8=13.2 \%\right)$. Assume that these large firms have sales that amount to $50 \%$ of GDP. The granularity regressions of Table 7 (column 1) suggest that if there is a $1 \%$ shock to sales of the largest firms with total sales accounting for 50\% of GDP, GDP growth will decrease by 0.3 percentage points $(0.591 / 2)$. These back-of-the-envelope calculations imply that the GDP growth effects of a $30 \%$ depreciation will be a decrease in growth of 4 percentage points $\left(0.3^{*} 13.2=3.96\right)^{28}$

In column 5 of Table 9, we pool all our observations but allow for the differential effect of firm size by estimating the following model:

$$
\begin{aligned}
\text { GR_Sales }_{i, c, t}= & \operatorname{LEV}_{i, c, t}\left(\beta+\gamma \Delta E X_{c t}+\phi \text { Large }_{i, c, t}+\psi \text { Large }_{i, c, t} \times \Delta E X_{c t}\right) \\
& +\delta \operatorname{Large}_{i, c, t}\left(\delta+\lambda \Delta E X_{c t}\right)+\alpha_{i}+\chi_{c, t}+\varepsilon_{i, c t, t}
\end{aligned}
$$

where $\chi_{c, t}$ is a country-year fixed effect and all other variables are defined as above. In this case our parameter of interest is $\psi$, which captures how firm size affects the impact on sales of the interaction between depreciation and leverage. We find that $\psi$ is negative, large in absolute value, and statistically significant. This confirms that the interaction between leverage and currency depreciations in absolute value is significantly larger for large firms.

Given that our panel is highly unbalanced with some countries in the sample with $>400$ listed firms while others with only 20 listed firms, we re-estimate our model by keeping a maximum of 150 firms per countryyear. The results remain near identical to what we obtain for the full sample of firms (compare columns 5 and 6 of Table 9).

Our findings are consistent with the hypothesis that many large firms may have unhedged foreign currency liabilities and are thus vulnerable to sudden currency depreciations. Given our previous evidence that idiosyncratic shocks to large firms affect overall economic activity, one is tempted to conclude that a sudden capital flows reversal could lead to very adverse effects on real output in emerging markets.

Such an adverse conclusion is however mitigated by the fact that, while the results of Table 9 are valid for the average emerging market country, there is substantial heterogeneity among the countries included in our sample. Fig. 6 reports the point estimates of the parameter $\psi$ obtained by estimating Eq. 13 (without the country-year fixed effects) separately for 14 countries in our sample. The point estimates range between -8 (Malaysia) and 15 (Philippines). They are negative for 10 countries and positive for 4 countries. Thus, there is substantial crosscountry heterogeneity and one challenge for future research will be to identify the drivers of this heterogeneity.

\section{Conclusion}

Using a rich firm-level dataset, this paper examines the surge in corporate leverage in emerging markets after the global financial crisis (GFC). The post-GFC period shows many emerging market economies close to or in the Altman Z-score "grey zone" implying a higher risk of corporate financial distress. We document a striking and robust empirical link between firm size and financial fragility and that currency depreciations amplify the vulnerability of large firms in our sample. A novel finding is that while the relationship between firm-leverage and distress scores varies over time, the relationship between firm size and corporate vulnerability is relatively time-invariant. In sum, all else equal, large firms in emerging markets are more financially vulnerable.

Given our findings about the relationship between firm size and financial fragility, a natural question arises about whether large firms are also systemically important. Following Gabaix (2011), we find that at a granular level, there is a positive and significant correlation between idiosyncratic shocks to the sales growth of large firms and overall GDP growth in our emerging markets sample. Large firms may therefore have the potential to transmit corporate distress to other firms in the economy through network effects and other spillovers. Although the large firms in our sample consistently have less leverage, the negative impact currency is more acute for the sales growth of large firms compared to similarly levered smaller firms, albeit with substantial crosscountry heterogeneity in the observed impacts.

To conclude, credit to emerging market firms has witnessed an unprecedented and rapid increase since the GFC. Gaining a better understanding of the relationship among corporate leverage, firm size and financial fragility in emerging market firms is of key policy relevance. Given the systemic importance of large and highly levered firms, our results suggest that policymakers ought to closely monitor this subset of emerging market firms.

\section{Acknowledgement}

We thank Harvard Business School for providing research funds.

\footnotetext{
${ }^{28}$ Note that $30 \%$ is larger than our sample average of $7 \%$ and is about twice as large as the typical currency depreciation but it is not an extreme event in emerging market countries. Note that the average depreciation, conditional on having a depreciation in our sample is $15 \%$ and $>10 \%$ of our observations have depreciation $>30 \%$. Currency crises are usually associated with monthly depreciation of $25 \%$, which is well above the $30 \%$ annual depreciation that we consider. If we redo our back of the envelope estimations using the average depreciation in our sample, i.e., $7 \%$, we find that the average depreciation is associated with a decrease in growth of approximately one percentage point $\left(55^{*} 0.07^{*} 0.8=3.08 \%\right.$ and $0.3 * 3.08=0.924$ )
} 


\section{Appendix A. Appendix}

\section{Table A1}

Sample sales and country market cap and GDP

\begin{tabular}{|c|c|c|}
\hline \multirow[t]{2}{*}{ Country } & (1) & (2) \\
\hline & $\overline{\text { Sales to Market Cap }}$ & $\overline{\text { Market Cap to GDP }}$ \\
\hline Argentina & $52 \%$ & $14 \%$ \\
\hline Brazil & $43 \%$ & $49 \%$ \\
\hline Chile & $51 \%$ & $111 \%$ \\
\hline China & $49 \%$ & $51 \%$ \\
\hline Colombia & $30 \%$ & $45 \%$ \\
\hline Eastern Europe & $100 \%$ & $34 \%$ \\
\hline India & $36 \%$ & $72 \%$ \\
\hline Indonesia & $34 \%$ & $39 \%$ \\
\hline Jordan* & $27 \%$ & \\
\hline Malaysia & $46 \%$ & $146 \%$ \\
\hline Mexico & $61 \%$ & $35 \%$ \\
\hline Morocco* & $12 \%$ & \\
\hline Pakistan & $107 \%$ & $16 \%$ \\
\hline Peru & $33 \%$ & $45 \%$ \\
\hline Philippines & $32 \%$ & $69 \%$ \\
\hline Russia & $116 \%$ & $26 \%$ \\
\hline South Africa & $23 \%$ & $225 \%$ \\
\hline South Korea & $119 \%$ & $78 \%$ \\
\hline Taiwan* & $93 \%$ & \\
\hline Thailand & $59 \%$ & $75 \%$ \\
\hline Turkey & $68 \%$ & $31 \%$ \\
\hline Vietnam & $79 \%$ & $13 \%$ \\
\hline
\end{tabular}

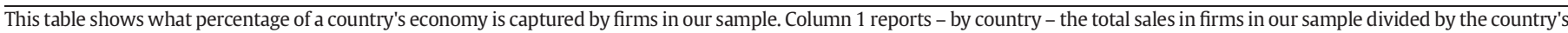
total market capitalization, as measured by the World Bank. Column 2 shows the ratio of total market capitalization and GDP in each country.

* No country-level market capitalization data. Value shows Sales / GDP instead.

\section{Table A2}

Leverage and Altman's EM Z-score heat maps

\begin{tabular}{|c|c|c|c|c|c|c|}
\hline \multirow[b]{2}{*}{ Country } & \multicolumn{3}{|c|}{ Leverage } & \multicolumn{3}{|c|}{ Altman's EM Z-score } \\
\hline & $1992-2014$ & 2003-07 & $2008-14$ & $1992-2014$ & $2003-07$ & $2008-14$ \\
\hline Argentina & $56 \%$ & $45 \%$ & $74 \%$ & 6.18 & 7.38 & 5.62 \\
\hline Brazil & $76 \%$ & $83 \%$ & $94 \%$ & 5.76 & 6.13 & 5.88 \\
\hline Chile & $90 \%$ & $82 \%$ & $93 \%$ & 6.45 & 6.44 & 6.20 \\
\hline China & $89 \%$ & $95 \%$ & $103 \%$ & 5.59 & 5.58 & 5.28 \\
\hline Colombia & $45 \%$ & $47 \%$ & $44 \%$ & 6.53 & 6.58 & 6.77 \\
\hline Eastern Europe & $47 \%$ & $48 \%$ & $55 \%$ & 6.22 & 6.49 & 6.30 \\
\hline India & $100 \%$ & $79 \%$ & $118 \%$ & 5.73 & 5.62 & 5.55 \\
\hline Indonesia & $78 \%$ & $81 \%$ & $72 \%$ & 6.42 & 6.36 & 7.13 \\
\hline Jordan & $66 \%$ & $81 \%$ & & 5.53 & 5.97 & 5.14 \\
\hline Malaysia & $66 \%$ & $69 \%$ & $63 \%$ & 6.95 & 6.95 & 7.77 \\
\hline Mexico & $65 \%$ & $59 \%$ & $89 \%$ & 6.73 & 6.26 & 5.53 \\
\hline Morocco & $68 \%$ & $42 \%$ & $128 \%$ & 6.95 & 7.47 & 5.04 \\
\hline Pakistan & $83 \%$ & $56 \%$ & $84 \%$ & 5.17 & 5.26 & 5.44 \\
\hline Peru & $56 \%$ & $53 \%$ & $68 \%$ & 7.11 & 7.23 & 6.99 \\
\hline Philippines & $103 \%$ & $103 \%$ & $131 \%$ & 6.28 & 6.02 & 6.11 \\
\hline Russia & $38 \%$ & $42 \%$ & $56 \%$ & 7.79 & 8.76 & 7.60 \\
\hline South Africa & $49 \%$ & $50 \%$ & $54 \%$ & 6.83 & 6.71 & 6.88 \\
\hline South Korea & $158 \%$ & $140 \%$ & $110 \%$ & 4.96 & 5.58 & 6.11 \\
\hline Taiwan & $63 \%$ & $66 \%$ & $66 \%$ & 6.73 & 6.80 & 7.03 \\
\hline Thailand & $119 \%$ & $84 \%$ & $83 \%$ & 5.56 & 6.21 & 6.32 \\
\hline Turkey & $105 \%$ & $104 \%$ & $124 \%$ & 6.54 & 6.30 & 5.80 \\
\hline Vietnam & $109 \%$ & $95 \%$ & $116 \%$ & 6.28 & 6.51 & 6.18 \\
\hline
\end{tabular}

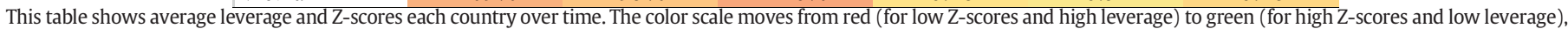
going through several shades of orange yellow. Jordan's 1992-2014 averaged until 2007 and Vietnam since 2003. 
Table A3

Balanced Sample

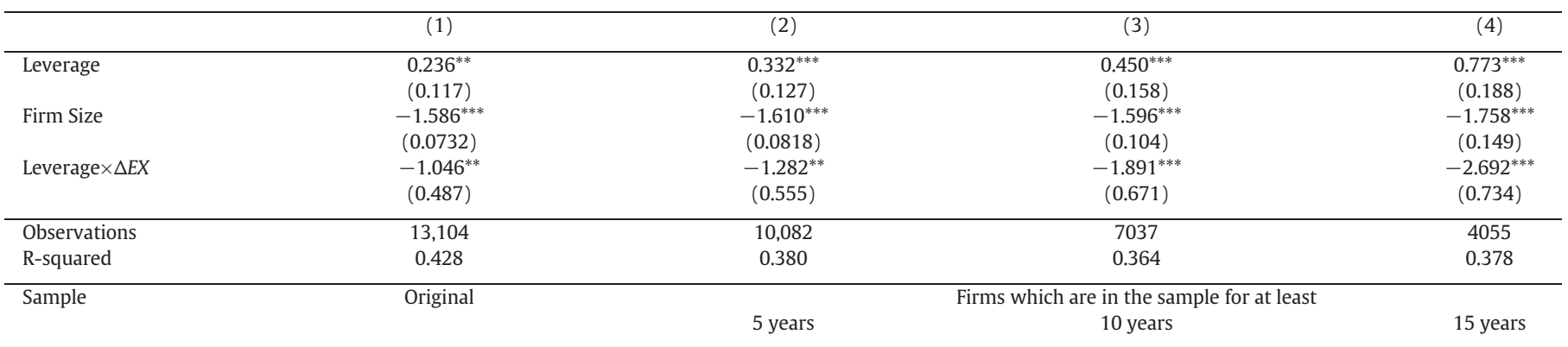

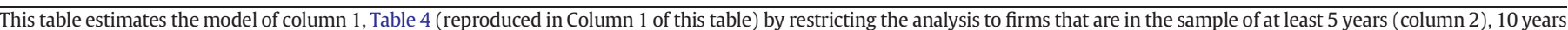
(column 3), and 15 years (column 4). Robust standard errors clustered at the firm and country-year level in parenthesis, ${ }^{* * *} \mathrm{p}<0.01,{ }^{* *} \mathrm{p}<0.05,{ }^{*} \mathrm{p}<0.1$

Table A4

Dropping China from the sample

\begin{tabular}{|c|c|c|c|c|c|c|}
\hline & (1) & (2) & (3) & (4) & (5) & (6) \\
\hline Leverage & $\begin{array}{l}0.313^{* *} \\
(0.123)\end{array}$ & $\begin{array}{c}0.251 \\
(0.214)\end{array}$ & $\begin{array}{l}0.875^{* *} \\
(0.348)\end{array}$ & $\begin{array}{c}0.231 \\
(0.216)\end{array}$ & $\begin{array}{c}0.209 \\
(0.288)\end{array}$ & $\begin{array}{c}0.329 \\
(0.604)\end{array}$ \\
\hline Firm Size & $\begin{array}{c}-1.593^{* * * *} \\
(0.0788)\end{array}$ & $\begin{array}{c}-1.593^{* * *} \\
(0.0785)\end{array}$ & $\begin{array}{c}-1.588^{* * *} \\
(0.0791)\end{array}$ & $\begin{array}{c}-1.595^{* * * *} \\
(0.0790)\end{array}$ & $\begin{array}{c}-1.612^{* * * *} \\
(0.0889)\end{array}$ & $\begin{array}{c}-1.603^{* * *} \\
(0.0892)\end{array}$ \\
\hline Leverage $\times \Delta E X$ & $\begin{array}{l}-1.177^{* *} \\
(0.519)\end{array}$ & $\begin{array}{l}-1.250^{* *} \\
(0.548)\end{array}$ & $\begin{array}{l}-1.311^{* *} \\
(0.523)\end{array}$ & $\begin{array}{c}-1.130^{* *} \\
(0.525)\end{array}$ & $\begin{array}{l}-1.244^{* *} \\
(0.518)\end{array}$ & $\begin{array}{l}-1.541^{* * *} \\
(0.556)\end{array}$ \\
\hline Leverage $\times G R \_G D P$ & & $\begin{array}{c}1.229 \\
(2.708)\end{array}$ & & & & $\begin{array}{c}2.999 \\
(3.478)\end{array}$ \\
\hline Leverage $\times$ Inflation & & & $\begin{array}{l}-0.141 \\
(0.0879)\end{array}$ & & & $\begin{array}{c}-0.0880 \\
(0.109)\end{array}$ \\
\hline Leverage $\times$ FINDEV & & & & $\begin{array}{c}0.00105 \\
(0.00236)\end{array}$ & & $\begin{array}{c}0.000108 \\
(0.00346)\end{array}$ \\
\hline Leverage $\times$ LMF & & & & & $\begin{array}{c}0.121 \\
(0.217)\end{array}$ & $\begin{array}{c}0.158 \\
(0.248)\end{array}$ \\
\hline Observations & 11,391 & 11,336 & 11,391 & 11,391 & 9635 & 9630 \\
\hline R-squared & 0.418 & 0.419 & 0.419 & 0.418 & 0.435 & 0.435 \\
\hline $\begin{array}{l}\text { Firm and Country-Year FE } \\
\text { Sample }\end{array}$ & $\begin{array}{l}\text { Yes } \\
\text { All }\end{array}$ & $\begin{array}{l}\text { Yes } \\
\text { All }\end{array}$ & $\begin{array}{l}\text { Yes } \\
\text { All }\end{array}$ & $\begin{array}{l}\text { Yes } \\
\text { All }\end{array}$ & $\begin{array}{l}\text { Yes } \\
\text { All }\end{array}$ & $\begin{array}{l}\text { Yes } \\
\text { All }\end{array}$ \\
\hline
\end{tabular}

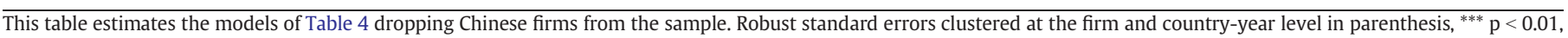
${ }^{* *} \mathrm{p}<0.05,{ }^{*} \mathrm{p}<0.1$

Table A5

Constant sample

\begin{tabular}{|c|c|c|c|c|c|c|}
\hline & (1) & (2) & (3) & (4) & (5) & (6) \\
\hline Leverage & $\begin{array}{l}0.357^{* * *} \\
(0.130)\end{array}$ & $\begin{array}{c}0.215 \\
(0.236)\end{array}$ & $\begin{array}{l}0.586^{*} \\
(0.322)\end{array}$ & $\begin{array}{l}0.407^{*} \\
(0.238)\end{array}$ & $\begin{array}{c}0.209 \\
(0.281)\end{array}$ & $\begin{array}{c}0.191 \\
(0.518)\end{array}$ \\
\hline Firm Size & $\begin{array}{c}-1.586^{* * *} \\
(0.086)\end{array}$ & $\begin{array}{c}-1.581^{* * *} \\
(0.085)\end{array}$ & $\begin{array}{c}-1.582^{* * *} \\
(0.086)\end{array}$ & $\begin{array}{c}-1.585^{* * *} \\
(0.086)\end{array}$ & $\begin{array}{c}-1.585^{* * *} \\
(0.086)\end{array}$ & $\begin{array}{c}-1.575^{* * * *} \\
(0.086)\end{array}$ \\
\hline Leverage $\times \Delta E X$ & $\begin{array}{c}-1.210^{* *} \\
(0.520)\end{array}$ & $\begin{array}{c}-1.391^{* *} \\
(0.555)\end{array}$ & $\begin{array}{c}-1.248^{* *} \\
(0.518)\end{array}$ & $\begin{array}{c}-1.237^{* *} \\
(0.531)\end{array}$ & $\begin{array}{c}-1.218^{* *} \\
(0.510)\end{array}$ & $\begin{array}{c}-1.496^{* * *} \\
(0.545)\end{array}$ \\
\hline Leverage $\times G R \_G D P$ & & $\begin{array}{c}2.481 \\
(2.957)\end{array}$ & & & & $\begin{array}{c}2.924 \\
(3.373)\end{array}$ \\
\hline Leverage $\times$ Inflation & & & $\begin{array}{l}-0.0613 \\
(0.0848)\end{array}$ & & & $\begin{array}{l}-0.051 \\
(0.082)\end{array}$ \\
\hline Leverage $\times$ FINDEV & & & & $\begin{array}{l}-0.001 \\
(0.003)\end{array}$ & & $\begin{array}{c}-0.001 \\
(0.00)\end{array}$ \\
\hline Leverage $\times$ LMF & & & & & $\begin{array}{c}0.129 \\
(0.215)\end{array}$ & $\begin{array}{c}0.210 \\
(0.233)\end{array}$ \\
\hline Observations & 10,278 & 10,278 & 10,278 & 10,278 & 10,278 & 10,278 \\
\hline R-squared & 0.443 & 0.443 & 0.443 & 0.443 & 0.443 & 0.443 \\
\hline $\begin{array}{l}\text { Firm and Country-Year FE } \\
\text { Sample }\end{array}$ & $\begin{array}{l}\text { Yes } \\
\text { All }\end{array}$ & $\begin{array}{l}\text { Yes } \\
\text { All }\end{array}$ & $\begin{array}{l}\text { Yes } \\
\text { All }\end{array}$ & $\begin{array}{l}\text { Yes } \\
\text { All }\end{array}$ & $\begin{array}{l}\text { Yes } \\
\text { All }\end{array}$ & $\begin{array}{l}\text { Yes } \\
\text { All }\end{array}$ \\
\hline
\end{tabular}

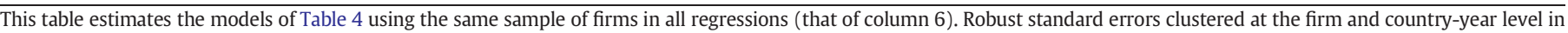
parenthesis, ${ }^{* * *} \mathrm{p}<0.01,{ }^{* *} \mathrm{p}<0.05,{ }^{*} \mathrm{p}<0.1$ 
Table A6

The granularity effect, additional controls.

\begin{tabular}{|c|c|c|c|c|c|c|c|}
\hline & (1) & $(2)$ & (3) & (4) & (5) & (6) & (7) \\
\hline G & $\begin{array}{c}0.829^{*} \\
(0.409)\end{array}$ & $\begin{array}{c}0.478^{*} \\
(0.258)\end{array}$ & $\begin{array}{l}0.609^{* *} \\
(0.257)\end{array}$ & $\begin{array}{l}0.479^{* *} \\
(0.222)\end{array}$ & $\begin{array}{l}0.661^{* *} \\
(0.254)\end{array}$ & $\begin{array}{l}0.602^{* *} \\
(0.230)\end{array}$ & $\begin{array}{l}0.588^{* *} \\
(0.243)\end{array}$ \\
\hline Debt to GDP & $\begin{array}{r}-0.010 \\
(0.020)\end{array}$ & & & & & & \\
\hline Financial depth & & $\begin{array}{l}0.040^{* * *} \\
(0.008)\end{array}$ & & & & & \\
\hline Trade balance & & & $\begin{array}{l}-0.086 \\
(0.061)\end{array}$ & & & & \\
\hline Government Consumption & & & & $\begin{array}{c}-0.505^{* *} \\
(0.221)\end{array}$ & & & \\
\hline Investment & & & & & $\begin{array}{l}0.224^{* * *} \\
(0.057)\end{array}$ & & \\
\hline Inflation & & & & & & $\begin{array}{l}-0.017 \\
(0.012)\end{array}$ & \\
\hline Ln(population) & & & & & & & $\begin{array}{l}4.796 \\
(3.353)\end{array}$ \\
\hline Observations & 197 & 452 & 462 & 462 & 462 & 467 & 467 \\
\hline R-squared & 0.497 & 0.515 & 0.492 & 0.509 & 0.533 & 0.481 & 0.483 \\
\hline Country fixed effects & Yes & Yes & Yes & Yes & Yes & Yes & Yes \\
\hline $\begin{array}{l}\text { Year fixed effects } \\
\text { Sample }\end{array}$ & Yes & Yes & Yes & $\begin{array}{c}\text { Yes } \\
1994-2014\end{array}$ & Yes & Yes & Yes \\
\hline
\end{tabular}

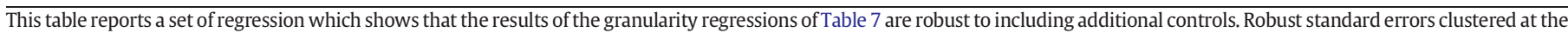
firm and country-year level in parenthesis, ${ }^{* * *} \mathrm{p}<0.01,{ }^{* *} \mathrm{p}<0.05,{ }^{*} \mathrm{p}<0.1$

Table A7

Leverage, depreciation and firm size, excluding China from the sample

\begin{tabular}{|c|c|c|c|c|c|c|}
\hline & (1) & (2) & (3) & (4) & (5) & (6) \\
\hline Leverage & $\begin{array}{c}0.123 \\
(0.133)\end{array}$ & $\begin{array}{c}0.112 \\
(0.134)\end{array}$ & $\begin{array}{c}0.389 \\
(0.282)\end{array}$ & $\begin{array}{c}0.004 \\
(0.152)\end{array}$ & $\begin{array}{c}-0.028 \\
(0.149)\end{array}$ & $\begin{array}{c}-0.194 \\
(0.225)\end{array}$ \\
\hline Leverage $\times \Delta E X$ & $\begin{array}{l}-0.082 \\
(0.074)\end{array}$ & $\begin{array}{l}-0.107 \\
(0.073)\end{array}$ & $\begin{array}{c}-0.804^{* * *} \\
(0.150)\end{array}$ & $\begin{array}{c}-0.0965 \\
(0.0857)\end{array}$ & $\begin{array}{l}-0.044 \\
(0.074)\end{array}$ & $\begin{array}{l}-0.044 \\
(0.075)\end{array}$ \\
\hline Large & $\begin{array}{c}-612.4^{* * *} \\
(36.86)\end{array}$ & $\begin{array}{c}-840.5^{* * *} \\
(47.09)\end{array}$ & & & $\begin{array}{c}-837.1^{* * * *} \\
(47.14)\end{array}$ & $\begin{array}{c}-750.0^{* * *} \\
(45.99)\end{array}$ \\
\hline$\triangle E X$ & $\begin{array}{l}-4.594 \\
(5.096)\end{array}$ & & & & & \\
\hline Large $\times \triangle E X$ & & & & & $\begin{array}{c}16.12 \\
(15.99)\end{array}$ & $\begin{array}{c}9.473 \\
(15.70)\end{array}$ \\
\hline Leverage $\times$ Large & & & & & $\begin{array}{c}0.537^{*} \\
(0.281)\end{array}$ & $\begin{array}{l}0.671^{* *} \\
(0.312)\end{array}$ \\
\hline Leverage $\times \Delta E X \times$ Large & & & & & $\begin{array}{c}-0.863^{* * *} \\
(0.167)\end{array}$ & $\begin{array}{c}-0.830^{* * *} \\
(0.168)\end{array}$ \\
\hline Observations & 31,454 & 31,454 & 8292 & 22,304 & 31,454 & 19,095 \\
\hline Number of firms & 0.100 & 0.119 & 0.260 & 0.127 & 0.120 & 0.197 \\
\hline Sample & All & All & Large Firms & Small Firms & All & Largest 150 \\
\hline Firm FE & Yes & Yes & Yes & Yes & Yes & Yes \\
\hline CY FE & No & Yes & Yes & Yes & Yes & Yes \\
\hline
\end{tabular}

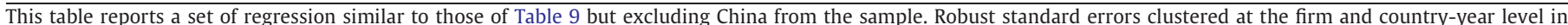
parenthesis, ${ }^{* * *} \mathrm{p}<0.01,{ }^{* *} \mathrm{p}<0.05,{ }^{*} \mathrm{p}<0.1$

Table A8

Name and description of variable

\begin{tabular}{|c|c|c|}
\hline Variable & Description & Source \\
\hline Altman's EM Z-score & $\begin{array}{l}6.56 \times 1+3.26 \times 2+6.72 \times 3+1.05 \times 4+3.25 \\
\mathrm{X} 1=\text { working capital/ total assets, } \mathrm{X} 2=\text { retained earnings /total assets, } \mathrm{X} 3=\text { operating income/total assets, } \\
\mathrm{X} 4=\text { book value of equity /total liabilities. }\end{array}$ & Worldscope, Osiris \\
\hline Debt-to-equity ratio & Total debt to common equity & Worldscope, Osiris \\
\hline Leverage & Total debt to common equity & Worldscope, Osiris \\
\hline Size & Log(total assets) & Worldscope, Osiris \\
\hline Investment & $\Delta$ property, plant \& equipment & Worldscope, Osiris \\
\hline$\Delta \mathrm{EX}$ & $\%$ change in nominal exch. rate (bilateral rate vs USD, $>0$ means appreciation) & World Bank, WDI \\
\hline & Financial liabilities weighted effective exchange rate & Benetrix, Lane, and Shambaugh (2015) \\
\hline GR & Real GDP growth & World Bank, WDI \\
\hline Inflation & Inflation & World Bank, WDI \\
\hline FINDEV & Private credit to GDP & World Bank, WDI \\
\hline LMF & Lane and Milesi-Ferretti (2007) index of financial globalization & Lane and Milesi-Ferretti (2007) \\
\hline G & Granularity index (see pp. 25-27) & Worldscope, Osiris \\
\hline Large (Tables 8,9 ) & Dummy if firm large (see pp. 26-27) & Worldscope, Osiris \\
\hline Solvency & EBITDA to total liabilities & Worldscope, Osiris \\
\hline Liquidity & Current to total liabilities & Worldscope, Osiris \\
\hline
\end{tabular}




\begin{tabular}{|c|c|c|}
\hline Variable & Description & Source \\
\hline Sales to market cap & Total sales of firms in our sample to each country's total market cap & Worldscope, Osiris, World Bank \\
\hline Market cap to GDP & Each country's total market cap to GDP & World Bank \\
\hline
\end{tabular}

\section{References}

Acemoglu, Daron, Ozdaglar, Asuman, Tahbaz-Salehi, Alireza, 2016. Networks, shocks, and systemic risk. In: Bramoullé, Yann, Galeotti, Andrea, Rogers, Brian (Eds.), Handbook of Network Economics. Oxford University Press, New York, NY, p. 2016.

Acharya, Viral, Davydenko, Sergei A., Strebulaev, Ilya A., 2011. Cash Holdings and Credit Risk (NBER Working paper 16995)

Acharya, Viral, Cecchetti, Stephen, De Gregorio, Jose, Kalemli-Özcan, Şebnem, Lane, Philip, Panizza, Ugo, 2015. Corporate Debt in Emerging Economies: A Threat to Financial Stability. Committee on International Policy Reform, Brookings Institutions and CIGI.

Ağca, Şenay, Celasun, Oya, 2012. Sovereign debt and corporate borrowing costs in emerging markets. J. Int. Econ. 88, 198-208.

Alfaro, Laura, Kanczuk, Fabio, 2013. Debt Redemption and Reserve Accumulation (NBER Working Paper Series, No. 19098).

Alfaro, Laura, Chari, Anusha, Kanczuk, Fabio, 2017. The real effects of capital controls: firm-level evidence from a policy experiment. J. Int. Econ. 108, 191-210.

Alfaro, Laura, Cuñat, Alejandro, Fadinger, Harald, Liu, Yanping, 2018. The Real Exchange Rate, Innovation and Productivity: Regional Heterogeneity, Asymmetries and Hysteresis (NBER Working paper 24633).

Allayannis, George, Weston, James, 2001. The use of foreign currency derivatives and firm market value. Rev. Financ. Stud. 14, 243-276.

Altman, Edward, 1968. Financial Ratios, discriminant analysis and the prediction of corporate bankruptcy. Journal of Finance 189-209.

Altman, Edward, 1993. Corporate Financial Distress and Bankruptcy. 2nd edition. John Wiley \& Sons, New York.

Altman, Edward, 2005. An emerging market credit scoring system for corporate bonds Emerg. Mark. Rev. 6, 3011-3323.

Avdjiev, Stefan, McCauley, Robert, McGuire, Patrick, 2012. Rapid Credit Growth and International Credit: Challenges for Asia. BIS Working Papers, no 377, April.

Avdjiev, Stefan, Chui, Michael, Shin, Hyun Song, 2014. Nonfinancial corporations from emerging market economies and capital flows. BIS Quarterly Review 67-77 December.

Avdjiev, Stefan, Bruno, Valentina, Koch, Catherine, Shin, Hyun Song, 2018. The dollar exchange rate as a global risk factor: Evidence from investment (BIS Working Papers, no 695, January).

Bank of International Settlement, 2014. Buoyant Yet Fragile? BIS Quarterly Review (December 2014).

Bank of International Settlement, 2016. Debt Securities Data Base. http://www.bis.org/ statistics/secstats.htm.

Ben-David, Itzhak, Franzoni, Francesco, Moussawi, Rabih, Sedunov, John, 2016. The Granular Nature of Large Investors (NBER Working Paper 22247).

Bénétrix, Agustin, Lane, Philip, Shambaugh, Jay, 2015. International currency exposures, valuation effects and the global financial crisis. J. Int. Econ. 96, 98-109 no 1.

Bernanke, Ben, Campbell, John, 1988. Is there a corporate debt crisis? Brookings Pap. Econ. Activity 19 (1), 83-137.

Bleakley, Hoyt, Cowan, Kevin, 2008. Corporate dollar debt and depreciations: much ado about nothing? Rev. Econ. Stat. 90 (4), 612-626.

Bonomo, Marco, Martins, Betina, Pinto, Rodrigo, 2003. Debt composition and exchange rate balance sheet effect in brazil: a firm level analysis. Emerging Markets Review 4 (4), 368-396.

Bonaccorsi di Patti, Emilia, Kashyap, Anil, 2017. Which Banks Recover From Large Adverse Shocks? NBER Working Papers 23654

Borio, C., McCauley, Robert, McGuire, Patrick, 2011. Global credit and domestic credit booms. BIS Quart. Rev. 43-57 September.

Bruno, Valentina, Shin, Hyun song, 2015b. Capital flows and the risk-taking channel of monetary policy. J. Monet. Econ. 71, 119-132.

Bruno, Valentina, Shin, Hyunsong, 2015a. Cross-border banking and global liquidity. Rev. Econ. Stud. 82 (2), 535-564.

Bruno, Valentina, Shin, Hyun Song, 2017. Global Dollar Credit and Carry Trades: A FirmLevel Analysis. Rev. Fin. Stud. 703-749.

Bussière, Matthieu, López, Claude, Tille, Cédric, 2015. Do real exchange rate appreciations matter for growth? Econ. Policy 30 (81), 5-45.
Caballero, Julian, Panizza, Ugo, Powell, Andrew, 2015. The Second Wave of Global Liquidity: Why are Firms acting like Financial intermediaries? (CEPR Working Paper, 10926)

Chari, Anusha, Henry, Peter Blair, 2015. Two tales of adjustment: east asian lessons for european growth. IMF Econ. Rev. 63 (1), 164-196.

Chinn, Menzie D., Ito, Hiro, 2006. What matters for financial development? Capital controls, institutions, and interactions. J. Dev. Econ. 81, 163-192.

Claessens, Stijn, Djankov, Simeon, Xu, Lixin Colin, 2000. Corporate performance in the east asian financial crisis. World Bank Res. Observ. 15 (1), 23-46.

Claessens, S., Tong, Hui, Zuccardi, Igor, 2015. Saving the Euro: mitigating financial or trade spillovers? J. Money Credit Bank. 47 (7), 1369-1402.

Corsetti, Giancarlo, Pesenti, Paolo, Roubini, Nouriel, 1999. What caused the Asian currency and financial crisis? Japan World Econ. Vol. 11, 305-373.

Corbae, Dean, D'Erasmo, Pablo, 2017. Reorganization or Liquidation: Bankruptcy Choice and Firm Dynamics NBER Working Papers 23515.

De Angelo, Harry, Goncalvez, Andrei S., Stulz, René M., 2016. Corporate Deleveraging. NBER Working Paper 22828

Di Giovanni, Levchenko, Andrei, 2013. Firm entry, trade, and welfare in Zipf's world. J. Int. Econ. 89, 283-296.

Druck, Pablo, Magud, Nicholas, Mariscal, Rodrigo, 2017. Collateral Damage: Dollar Strength and Emerging Markets' Growth (IMF Working Paper, WP/15/179).

Du, Wenjin, Schreger, Jesse, 2016. Local currency sovereign risk. J. Financ. 71 (3), 1027-1070.

Eichengreen, Barry, Tong, Hui, 2015. Effects of renminbi appreciation on foreign firms: The role of processing exports. J. Dev. Econ. 116 (C), 146-157.

Fazzari, Steven M., Hubbard, R. Glenn, Petersen, Bruce C., 1988. Financing constraints and corporate investment. Brook. Pap. Econ. Act. 1, 141-206.

Gabaix, Xavier, 2011. The granular origins of aggregate fluctuations. Econometrica 79, 733-772.

Galindo, Arturo, Panizza, Ugo, Schiantarelli, Fabio, 2003. Debt composition and balance sheet effects of currency depreciation: a summary of the micro evidence. Emerg. Markets Rev. Elsevier 4 (4), 330-339.

Ghosh, Atish, Lane, Timothy, Schultze-Ghattas, Marianne, Bulir, Ales, Hamann, Javier, Mourmuras, Alex, 2002. IMF-Supported Programs in Capital Account Crises. Occasional Paper 210. International Monetary Fund, Washington.

Graham, John R., Li, Si, Qiu, Jiaping, 2008. Corporate misreporting and bank loan contracting. J. Financ. Econ. 89 (1), 44-61.

IMF, 2015. Corporate leverage in emerging markets-A concern? Vulnerabilities, Legacies, and Policy Challenges Risks Rotating to Emerging Markets, Global Financial Stability Report, October. Washington D.C

Jacobson, Tor, Von Schedvin, Erik, 2015. Trade credit and the propagation of corporate failure: an empirical analysis. Econometrica 4, 1315-1371.

Lane, Philip, McQuade, Peter, 2014. Domestic credit growth and international capital flows. Scand. J. Econ. 116, 218-252 no 1.

Lane, Philip, Milesi-Ferretti, Gian Maria, 2007. The external wealth of nations mark II: Revised and extended estimates of foreign assets and liabilities, 1970-2004. J. Int. Econ. 73, 223-250

McCauley, Robert, McGuire, Patrick, Sushko, Vladyslav, 2015. Dollar credit to emerging market economies. BIS Quarterly Review 27-41.

Mendoza, Enrique and Marco E. Terrones, E. (2008) "An anatomy of credit booms: evidence from macro aggregates and micro data," NBER WP 14049.

Niepmann, Friedrich, Schmidt-Eisenlohr, Tim, 2017. Foreign Currency Loans and Credit Risk: Evidence from U.S. Banks CESifo Working Paper, 67002017.

Pomerlano, Michael, 1998. The East Asian crisis and corporate finances: the untold microeconomic story. Emerg. Mark. Q. (Winter), 14-27.

Schularick, Moritz, Taylor, Alan M., 2012. Credit books gone bust: monetary policy, leverage cycles, and financial crises: 1870-2008. Am. Econ. Rev. 102 (2), 1029-1061.

Shin, Hyun Song, 2013. The second phase of global liquidity and its impact on emerging economies. Proceedings of the Asia Economic Policy Conference, Federal Reserve Bank of San Francisco.

Van Binsbergen, Jules, Graham, John R., Yang, Jie, 2010. The cost of debt. J. Financ. 65, 2089-2136. 